\title{
Nabumeton İçeren Tabletlerde Yeni Miktar Tayin Yöntemleri ve Diğer Yöntemlerle Karşılaştırması
}

\author{
Yalçın EROĞLUS
}

Erzincan Binali Yıldırım Üniversitesi Eczacılık Fakültesi Eczacılık Meslek Bilimleri Bölümü, 24100, Erzincan

Geliş / Received: 21/01/2020, Kabul / Accepted: 16/03/2020

\begin{abstract}
Öz
Türkiye'de Relifex film tablet adı altında satılan ve non-steroidal antienflamatuvar etkili, romatoid artrit ve osteoartrit tedavisinde endike bir bileşik olan nabumetonun preparatlardaki miktarlarının tayini için yeni yöntemler geliştirilmiştir. Çalışmada, HPLC, HPTLC, ${ }^{1} \mathrm{H}-\mathrm{NMR}$ ve LC/MS yöntemleri olmak üzere dört yeni yöntem geliştirilmiş ve bulunan yöntemler ticari tabletlere uygulanmıştır. Dört ayrı yöntemin sonuçları istatistiksel olarak değerlendirilmiş ve kendi aralarında hassasiyet, çabukluk, kolay uygulanabilirlik ve ekonomik yönden karşılaştırılması yapılmıştır. Geliştirilen bu yeni yöntemler günümüzde rutin analizlerde uygulanan UV yönteminden daha hassas ve daha iyidir. Bu çalışmayla, ilaç sanayinde ve ilaçların piyasa ile ruhsat aşamasındaki kontrollerinde teknolojinin yakından takip edilmesi gerekliliği açıkça ortaya konulmaktadır. Kantitatif ilaç analizlerinde daha kesin sonuç veren, kolaylıkla uygulanabilen ve insan hatasının en aza indirgendiği yeni cihazları kullanmak ve birlikte getirdikleri modern teknolojilerle analizleri gerçekleştirmek kaçınılmazdır.
\end{abstract}

Anahtar Kelimeler: Nabumeton, LC/MS, HPTLC, ${ }^{1} \mathrm{H}-\mathrm{NMR}$

\section{New Determination of Nabumetone-containing Tablets and Their Comparison with Other Methods}

\begin{abstract}
Abctract
New methods have been developed to determine the amount of nabumetone in preparations sold under the commercial name "Relifex" in Turkey, to treat the symptoms related to the rheumatoid arthritis and osteoartritis as a non- steroidal anti-inflammatory drug. In this work, four different new methods, HPLC, HPTLC, 1H-NMR and LC/MS have been developed and applied to commercial tablets. The results of all these four different methods are compared and inter comparison of these results with respect to sensitivity, ease of applicability and the coşt are made between themselves. All these new methods developed are better and more sensitive than UV methods used in routine analysis nowadays. İ this study, it is obviously understood that the new techniques should be considered in controls and registration of the drugs. It is necessary to make the analysis by using modern techniques and to use new instrumentations to have more definite results in quantitative analysis and to make easy analytic applications and to decrease errors.
\end{abstract}

Keywords: Nabumetone, LC/MS, HPTLC, ${ }^{1} \mathrm{H}-\mathrm{NMR}$

\section{Giriş}

\subsection{Non-Steroidal Antienflamatuvar İlaçlarla İlgili Genel Bilgiler}

\subsubsection{Non-Steroidal Antinflamatuvar İlaçların Kullanımı}

Non-steroidal antienflamatuvar ilaçlar toplumda, kas-iskelet ağrıları ve diğer ağrılı durumlarda sıklıkla kullanılan ilaçlardır. Bu ilaçların geniş kullanımı, toplumda romatizmal hastalıkların sıklı̆ı̆ını yansıtabilir. Pratisyen doktorlara yapılan başvuruların en sık nedenlerinden biri kas-iskelet ağrılarıdır. NSAII'lar enflamatuvar hastalıkların 
semptomatik tedavisinin temelini oluşturmaktadır. Yaşlanma ile bu tür ilaçlara ihtiyaç artmaktadır. NSAIII'lar romatik olmayan hastalıklarda, akut-kronik ağrılarda, safra, üretra, kolit ve adet düzensizliklerinde kullanılmaktadır. Bu tür ilaçların reçeteli ve reçetesiz kullanımı her yıl artış göstermektedir. Hastalar arasında bu ilaçlara verilen cevapta çeşitlilik olabilir. Protein bağlanması, ilacın metabolik profili gibi bazı faktörler insanlar üzerindeki etkiyi değiştirebilir. Bazı NSAİI’lar optikçe aktiftirler. Bunlar, aril propiyonik asit türevleridir. Bu grup ilaçlar inaktif "R" ve aktif "S" enantiomerlerinin karışımı şeklindedir (Ibuprofen, ketoprofen ve flurbiprofen). Etkin "S" izomerlerinin preparat içindeki yüzdesi de ilaca olan cevabı değiştiren faktörlerdendir (Brooks, P).

Non-steroidal antienflamatuvar ilaçlar, ilaç bağımlılığı yapmadıklarından ve uyuşukluk ve bilinç bulanıklığı şeklinde nitelenen narkoz hali oluşturmadıklarından ağrılı hastalıkların semptomatik tedavisinde tercih edilmektedir. Özellikle artrit, osteoartrit ve benzeri romatizmal hastalıklar gibi genellikle enflamasyona bağlı ve uzun süre analjezik ilaç verilmesini gerektiren durumlarda yararlıdırlar. Bağımlılık yapmamaları, antienflamatuvar etkilerinin yanı sıra terapötik etkilerine karşı tolerans oluşmaması bu grup ilaçların değerini artırmaktadır (Kayaalp, S.O.).

NSAIII'ların kullanımı ve genel etkileri ele alınmış, sıklıkla reçete edilen bu grup ilaçların kas-iskelet ağrılarında, enflamasyon, migren baş ağıları, adet düzensizliği ve kardiyovasküler hastalıkların tedavisinde kullanımı ve çok iyi tolere edildiklerini belirtilmiştir(Mandell, B.F.)

$\mathrm{Bu}$ grup ilaçların tat alma reseptörleri üzerindeki doğrudan etkileri araştırıldığında yaşlı kişiler gençlerden daha yüksek eşiğe sahip bulunmuştur. İlaçların çoğu doğrudan dile uygulandığı zaman sodyum klorür gibi besinlerin tatlarını değiştirdikleri tespit edilmiştir(Mandell, B.F. ve ark.).

\subsubsection{Non-Sterodial Antienflamatuvar İlaçların Sınıflandırmaları}

Non-steroidal antienflamatuvar ilaçlar kimyasal yapılarına göre beş gruba ayrilırlar(Akgün, H. ve ark.).

- Salisilik asit ve türevleri

- Anilin ve p-aminofenol türevleri

- 5-Pirazolon ve 3,5-pirazolidindion türevleri

- N-Arilantranilik asit türevleri

- Aril ve heteroarilasetik asit türevleri -İndolasetik asit türevleri -Pirolasetik asit türevleri -Fenilasetik asit türevleri -Naftalenpropionik asit türevleri -Enolik asitler-oksikanlar -Aril asetik asit prekürsörleri

- Değişik yapıdaki bileşikler

Yapılan bu sinıflandırmaya göre nabumetonun aril asetik asit prekürsörleri grubunda yer aldığ 1 bildirilmiştir.

\subsection{Kantitatif Analizler}

\subsubsection{HPLC Yöntemi}

Müstahzarın üreticisi olan firma spesifikasyonuna göre uygulanan yöntem nabumetonun normal faz HPLC ile kromatografik olarak ayrılıp saflığı bilinen bir referans standart ile mukayese edilerek tayini esasına dayanır. 
Cihaz: Uygun bir pompa, enjektör, ayırma kolonu ve ultraviyole detektörü ve elektronik entegrasyona sahip bir yüksek performanslı s1v1 kromatograf olmalidır.

\section{Kimyasal Maddeler:}

-Saflık yüzdesi belli nabumeton standartı

-1,2-dikloroetan — analitik saflıkta HPLC elüenti

\section{Çalışma şartları:}

1. Hareketli faz: Analitik kalitede 1,2dikloroetan

2. Kolon: $25 \mathrm{~cm}$ x $5 \mathrm{~mm}$ iç çaplı, $5 \mu$ 'luk silika ile doldurulmuş paslanmaz çelik kolon

3. Deteksiyon: $254 \mathrm{~nm}$

4. Akış Hızı: 1,2 mL/ dk

5. Sicaklık: Oda sicaklığı

$\mathrm{Bu}$ şartlarda çalışıldığında nabumetonun alıkonma zamanı yaklaşık olarak 6 dakika olarak belirtilmiştir.

\section{İşlem:}

Numune ve referansin, 1,2-dikloroetanda yaklaşı $0,2 \mathrm{mg} / \mathrm{mL}$ civarı konsantrasyonları paralel olarak hazırlanır. Numune ve standart çözeltisinden yapılan enjeksiyonlardan elde edilen kromatogamlardaki piklerin elektronik entegrasyonla pik alanları hesaplanır.

\section{HESAPLAMA:}

Her bir numune enjeksiyonu için, ilgili referans enjeksiyonunun ortalamasına karşı miktarı hesaplanır.

$\%$ Nabumeton $=\frac{A_{2} \times W_{1} \times V_{2} \times \mathrm{P}}{A_{1} \times W_{2} \times V_{1}}$
$\mathrm{A}_{1}=$ Referans standart kromatogramındaki nabumeton pik alanı

$\mathrm{A}_{2}=$ Numune kromatogramındaki nabumeton pik alanı

$\mathrm{W}_{1}=$ Referans standart ağırlığ $(\mathrm{g})$

$\mathrm{W}_{2}=$ Numune ağırlığ $(\mathrm{g})$

$\mathrm{V}_{1}=$ Referans standartın seyreltildiği hacim

$\mathrm{V}_{2}=$ Numunenin seyreltildiği hacim

$\mathrm{P}=$ Referans standartın tayin edilmiş \% saflı̆̆

Nabumeton'un (4-(metoksi-2-naftil)-butan-2on) İngiliz Farmakopesi ile Avrupa Farmakopesinde monografının yer aldığ bilinmektedir. Adı geçen farmakopelerdeki miktar tayini ile ilgili yöntem HPLC yöntemidir.

İngiliz Farmakopesinde yer alan nabumeton tablet monografinda belirtilen yönteme ait şartlar aşağıda verilmiştir(British Phamacopoeia 1998).

\section{Kromatografik şartlar:}

a ) Kolon: Spherisorb S5W ( $5 \mu \mathrm{m}, 25 \mathrm{~cm} \mathrm{x}$ 4,6 mm), paslanmaz çelik.

b ) Hareketli Faz: 1,2-dikloroetan

c ) Akış Hızı: 2 mL / dk

d ) Detektör: UV, $254 \mathrm{~nm}$

Çözelti (1) : 5 g nabumetona eşdeğer tablet

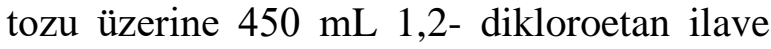
edilir ve ultrasonik banyoda 15 dakika karıştırılıp $500 \mathrm{~mL}$ ' ye tamamlanır. Whatman GF / C filtre kağıdından süzülür. Süzüntüden $5 \mathrm{~mL}$ alınarak 1,2-dikloroetan ile $250 \mathrm{~mL}$ ' ye tamamlanır. 
Çözelti (2) : 1,2-dikloroetan içinde nabumetonun \% 0,02 ( w/v )' lik çözeltisi hazırlanır.

Çözelti (3) : Nabumeton ve 5-(6-metoksi-2naftil)-3-metilsikloheksan-1-onun dikloroetan içinde \% $\quad 0,002^{\prime}$ lik (w/v) çözeltisi hazırlanır.

Açıklanan şartlarda çözelti (2) ile elde edilen komatogramdaki temel pikin alıkonma zamanının yaklaşık 5 dakika olduğu belirtilmiştir. Çözelti (3) ile elde edilen kromatogramda nabumeton ve 5-( 6-metoksi2-naftil )-3-metilsikloheksan-1-onun ayırım faktörü 3 'den az olduğunda yöntemin geçerli olmadığı açıklanmıştır.

Avrupa Farmakopesinde yer alan nabumeton monografında belirtilen HPLC yöntemi ile ilgili şartlar ise aşağıda açıklandığı gibidir(European Pharmacopoeia 2001).

\section{Kromatografik șartlar:}

a ) Kolon: Oktadesilsilil silikajel kaplı ( 4 $\mu \mathrm{m}, 15 \mathrm{~cm} \mathrm{x} \mathrm{4,6} \mathrm{mm)} \mathrm{paslanmaz} \mathrm{çelik.}$

b ) Hareketli Faz A: Tetrahidrofuran: asetonitril : \% 0,1 ( v/v ) glasiyal asetik asit ( 12: $2: 60$ )

Hareketli Faz B: Tetrahidrofuran: asetonitril : $\%$ 0,1 ( v/v ) glasiyal asetik asit ( 2: 56: 20 )

c ) Akış Hızı: $1 \mathrm{~mL} / \mathrm{dk}$

d ) Detektör: UV- detektör, $254 \mathrm{~nm}$

e) Kolon Sicaklı̆̆ $40{ }^{0} \mathrm{C}$

Yukarıda bahsedilen şartlarda yöntem uygulandığı zaman hareketli faza karşı zaman profili Tablo 1' da verilmiştir. Belirtilen şartlarda çalışıldığında nabumeton için alıkonma zamanı yaklaşık olarak 11 dakika olarak bildirilmiștir.
Tablo-1. Nabumetonun hareketli faza karşı zaman profili

\begin{tabular}{|l|l|l|l|}
\hline Zaman(Dakika) & $\begin{array}{l}\text { Hareketli Faz } \\
\mathrm{A}(\% \mathrm{v} / \mathrm{v})\end{array}$ & $\begin{array}{l}\text { Hareketli Faz } \\
\mathrm{B}(\% \mathrm{v} / \mathrm{v})\end{array}$ & Açıklama \\
\hline $0-12$ & 100 & 0 & İzokratik \\
\hline $12-28$ & $100>0$ & $0 \triangleright 100$ & $\begin{array}{l}\text { Lineer } \\
\text { Gradient }\end{array}$ \\
\hline $28-33$ & 0 & 100 & İzokratik \\
\hline $33-34$ & $0 \triangleright 100$ & $100 \triangleright 0$ & $\begin{array}{l}\text { Lineer } \\
\text { Gradient }\end{array}$ \\
\hline $34-35$ & 100 & 0 & İzokratik \\
\hline
\end{tabular}

\subsubsection{LC/MS Yöntemi}

Atmosferik basınçlı iyonizasyon tekniği ile çok zayıf iyonize olduğu belirtilen nabumetonun bazı safsızlıklarının yapısal aydınlatılması için sıvı kromatografisi / partikül demeti kütle spektrometresi (LC/PBMS) tekniği nabumeton için optimize edilmiş ve hassaslık çalışması yapılmıştır. Spektrumların elde edilebilmesi için en az 100 ng maddeye ihtiyaç duyulduğu bildirilmiştir (Wolff, J.C. ve ark.).

\section{Kromatografik şartlar:}

Kolon: Oktadesilsilan kaplı paslanmaz çelik Kolon (2,1 X 150 mm)

Akış hızı: $300 \mu \mathrm{L} / \mathrm{dk}$

Hareketli faz: 0,05 M amonyum asetat: asetonitril (60: 40)

Kolon sicaklığı: $40{ }^{0} \mathrm{C}$

Detektör: UV ( $254 \mathrm{~nm}$ )

Enjeksiyon hacmi: Çalışma koşullarına bağlı olarak $10 ; 20 ; 50$ ve $100 \mu \mathrm{L}$

\section{Kütle spektrometresi:}

Deney sirasinda $70 \mathrm{eV}$ 'da pozitif iyonizasyon ile çalışılmıştır. İyi nebulizasyon şartları için parametreler ve duyarlılık model maddeler olarak nabumeton (alıkonma zamanı 9,8 dk) ve $1,5-\quad b i s(6-m e t o k s i-2-n a f t a l e n i l)-3-$ 
pentanon (alıkonma zamanı 24,8 dk) kullanılarak optimize edilmiştir. Optimal nebulizer sıcaklığı $80-85{ }^{0} \mathrm{C}$, ekspansiyon bölgesi için $75{ }^{\circ} \mathrm{C}$ ve iyon kaynağı için 200 ${ }^{0} \mathrm{C}^{\prime}$ de çalışılmıştır.

ESI kaynağını kullanarak plazmadaki farmasötiklerin hızlı biçimde tespitinde büyük partikül ölçülü sabit fazların ve yüksek akış hızlı LC/MS 'in artan kullanımının çalışıldığı teknik, plazma örneklerinde ilaçların tespitine olanak sağlamış ve çekici olarak bildirilmiştir (Bayliss, M.K. ve ark.).

Duncan, LC/MS ile miktar tayini yönteminin kütle spektroskopisinin en hızlı gelişen bir parçası olduğunu belirtmiş ve yöntemin temel prensiplerini, limitlerini açıklamış ve konu ile ilgili yapılan çalışmaları özetlemiştir (Duncan, M.W. ve ark.).

\subsection{3. ${ }^{1} \mathrm{H}-\mathrm{NMR}$ Spektroskopisi İle Miktar Tayini Yöntemi}

NMR spektroskopisinin, özellikle yap1 açıklamaları olmak üzere kinetik, termodinamik ve mekanizma çalışmalarında kullanılabilirliği olduğu gibi kantitatif analiz amacıyla da oldukça fazla bir kullanıma sahip olduğu bilinmektedir.

Kantitatif analizde iki tip çalışma yapılmaktadır.

a) Herhangi bir standart kullanmadan sinyallerin bağıl şiddet değerlerinden hareketle numuneyi oluşturan karışımların oranlarını bulmak,

b) Herhangi bir numune içinde istenilen bileşiğin dışarıdan ilave edilen bir standart ile karşılaştııılması suretiyle miktarını tespit etmek,
Her iki çalışmada sinyalin absorbe ettiği enerji miktarı yani integral değeri kullanılmaktadır. Cihazlar üzerinde otomatik olarak yapılan bu işlemle her sinyalin absorbe ettiği enerji miktarı alansal ve sayısal değerlerle verilmektedir. Böylece saf bir bileşiğin spektrumunda çeşitli protonların oranları tespit edilebilmekte ve teşhisi mümkün olabilmektedir. Bilinen bileșiklerin karışımlardaki kantitatif tayinleri, bileşiklere ait sinyallerin integral değerleri ile yap1labilmektedir.

Miktarı bilinmeyen bir bileşiğin tayini ise ortama belli bir miktarda başka bir bileşik ilavesi ile yapılmakta ve spektrumdaki integral değerleri karşılaştırılmaktadır. İlave edilen bileşik standart olarak isimlendirilmekte ve ortama iç veya diş olarak ilave edilebilmektedir.

Miktar tayininde bilinmeyen bileşiğin miktarı aşağıdaki formül ile kolayca bulunabilmektedir.

$W_{u=} W_{s} *\left(\frac{A_{u}}{A_{s}}\right) *\left(E_{u} / E_{s}\right)$

Formülde:

$\mathrm{W}_{\mathrm{u}}=$ Numunenin $\mathrm{mg}$ cinsinden miktarı

$\mathrm{W}_{\mathrm{s}}=$ Standartın $\mathrm{mg}$ cinsinden miktar 1

$\mathrm{A}_{\mathrm{u}}$ =Numunenin özel olarak seçilen sinyalinin integral değeri

$\mathrm{A}_{\mathrm{s}}=$ Standartın özel olarak seçilen sinyalinin integral değeri

$\mathrm{E}_{\mathrm{u}}=$ Numunenin proton ekivalan ağırlığ (M.Ağ. /sinyali veren proton sayısı)

$\mathrm{E}_{\mathrm{s}}=$ Standartın proton ekivalan ağırlığ (M.A $\breve{g} . /$ sinyali veren proton sayıs1) 
Formülde kullanılan değerler spektrumun incelenmesi sonucu kolayca bulunabilen değerlerdir.

Miktar tayini çalışmalarına kolaylık sağlamak üzere standart olarak kullanılabilecek bileşikler Siklohekzan, asetik asit, malonik asit, nitrometan, metilen klorür, benzil benzoat, fumarik asit, maleik anhidrit gibi bileşiklerdir. NMR spektroskopisi kullanılarak yapılan kantitatif analiz yönteminin yapılışı USP XXIII'de belirtilmiştir(USP 23 1995).

NMR yönteminin diğer yöntemlere olan üstünlüğü tartımın doğru alınması koşuluyla kullanıcıdan kaynaklanan hatanın en aza indirgenmesidir. Böylelikle sonuçlar daha kesin alınabilmekte ve analizin çok kısa zamanda bitirilmesi mümkün olmaktadır.

Meprobamatın farmasötik preparatlarda ${ }^{1} \mathrm{H}$ NMR spektroskopisi yöntemi ile tayinininde iç standart olarak malonik asit kullanılmış, meprobamatın 3.38 ppm'deki metilen grubunun sinyali, malonik asitin ise 3,40 ppm'deki metilen grubnuna ait sinyal kullanılarak miktar tayini verilmiştir (Turzcan, J.W. ve ark.). Noyanalpan ve Özden, aynı yöntemi Türkiye'de satılan meprobamat ihtiva eden preparatlara uygulamış ve sonuçları NF-XXII'de açıklanan yöntemle hız, hassasiyet ve kolaylık bakımından karşılaştırmışlardır (Noyanalpan, N. ve ark.).

Non-steroid antienflamatuvar, analjezik etkili bir ilaç olan indometasinin ${ }^{1} \mathrm{H}-\mathrm{NMR}$ spektroskopisi yöntemi ile miktar tayini için yapılan çalışmada iç standart olarak mandelik asit, çözücü olarak aseton- $\mathrm{d}_{6}$ kullanılmış ve yöntem hiz, hassasiyet, kolay uygulanabilirlik bakımından USP XX ile NFXXIII'de verilen yöntemler ile karşılaştırılmıştır (Özden, S. ve ark.).

\subsubsection{Yüksek Performanslı İnce Tabaka Kramotagrafisi ile Miktar Tayini Yöntemi}

Numunede bulunan bileşenlerin miktarının kantitatif tayini, lekelerin alanının standarta ait lekenin alanının karşılaştırılması ile yapılmaktadır. Plaka üzerinden lekenin kazınmas1, analitin durgun fazdan ekstraksiyonu ve uygun bir fiziksel veya kimyasal yöntemle ölçülmesiyle daha iyi veriler elde edilebilmektedir. Tarayıcı bir dansitometre kullanarak lekenin yaydığ yansıma ışınlarını ölçerek uygulanan yöntem daha büyük kolaylıklar sağlamaktadır (Skoog, D.A. ve ark.).

Kaplı tabletlerde siprofloksazinin safsızlık kontrolü ve belirlenmesi için yüksek performanslı ince tabaka kromatagrafisi (HPTLC) yöntemi geliştirilmiştir. Dezfloro bileşiği, etilendiamin ve florokinolonik asit safsılılılar olarak değerlendirmiş ve kaplı tabletlerdeki siprofloksazin ile ilgili safsızlık sonuçları HPLC ile karşılaştırmış ve sonuçların benzerlik gösterdiği tespit edilmiştir (Novakovic, J. ve ark.).

Farmasötik dozaj formlarından nimesulidin HPTLC ile miktar tayini için verilen yöntemde nimesulid ve bozuma ürünleri araştırılmış, kalibrasyon eğrisi hazırlanmış ve detekte edilen en düşük limit (LOD) ile kantitatif alt limit (LOQ) tespit edilmiştir (Patravale, V.B. ve ark.).

Psödoefedrin ve setrizin içeren formülasyonlarda, hızlı, seçici ve kararlı gösteren HPTLC yöntemini geliştirmiş ve valide etmiştir. İki etken maddenin bir arada belirlenmesi için yöntem tekrarlanabilir ve seçici bulunmuştur (Makhija, S.N. ve ark.).

Gastrointestinal fonksiyonu etkileyen bazı jenerik ilaçların analizi için HPTLC yönteminin geçerliliğinin bildirildiği yöntem 
ranitidin $\mathrm{HCl}$ ve ursodeoksikolik asite uygulanmıştır (Novakovic, J. ve ark.).

Piroksikam'nn kantitatif tayini ve tespiti HPTLC ve HPLC yöntemi ile yapılmış, yöntemler performans ve kesinlik bakımından karşılaştırılmıştır (Bartsch, H. ve ark.).

\section{Materyal ve Metot}

\subsection{Kullanılan Cihazlar}

NMR Spektrometresi: Bruker DPX 400, $400 \mathrm{MHz}$ Yüksek Performanslı Dijital FT NMR Spektrometresi

Yüksek Basınçlı Sıvı Kromatograf (HPLC): Thermoquest marka SprecrtaSystem s1v1 kromatografi sistemi; SCM1000 Vakum degasser, P400 4'lü Gradient pompa, AS3000 Otomatik örnekleyici ve kolon firını, UV6000 LP diode array dedektöri C18 ters faz kolon (150x4,6 $\mathrm{mm})(50 \mathrm{x} 4,6 \mathrm{~mm})$

Yüksek Performanslı İnce Tabaka Kromotagraf (HPTLC): Automatic CAMAG TLC Sampler

IR- Sprektrometresi: Shimadzu Infrared Sprektrometresi IR-435

Sıvı Kromotograf/Kütle Sprekrometresi (LC/MS): Thermoquest Spectrasistem Siv1 kromatograf sistemi ve Thermoquest Finnigan AQA Kütle Spektrometresi

Ultrasonik Banyo: Cole-Parmer Ultrasonic Cleaner

Hassas Terazi: Presica 205 ASCS Swiss Quality

\subsection{Kullanılan Kimyasallar}

Çalışmada kullanılan bileşiklerden DMSO$\mathrm{d}_{6}$, metanol (HPLC dereceli),
kloroform(HPLC dereceli) Merck/ Almanya'dan temin edilmiştir. Benzil benzoat Hıfzıssıhha Merkez başkanlığı İlaç ve Kozmetikler Araştırma Müdürlüğü, Antiseptik Laboratuvarından temin edilmiştir.

\subsection{Kullanılan Standart Nabumeton'un Teşhisi Ve Saflığının Analizi}

Deneylerde standart olarak kullanilan nabumeton Hıfzıssıhha Merkezi Başkanlığı, İlaç ve Kozmetikler Araştırma Müdürlüğü, Analjezik laboratuvarından temin edilmiş ve İnfrared Spektrumu ile ergime derecesi tayin edilerek literatürde verilen değerler ile karşılaştırılmıştır (Goudie, A.C. ve ark.).

\subsection{NMR Miktar Tayini Yönteminin Uygulanışı}

\subsection{1. ${ }^{1}$ H-NMR Spektroskopisi}

\subsubsection{Nabumeton Referans Standartına Uygulanması}

$10 \mathrm{mg}$ civarında tam tartılmış nabumeton üzerine $15 \mathrm{mg}$ civarında yine tam tartılmış benzil benzoat eklendi. $2 \mathrm{~mL}$ DMSO- $\mathrm{d}_{6}$ içerisinde karıştırılarak çözülen karışımın NMR spektrumu alındı.

Nabumetonun ${ }^{1} \mathrm{H}-\mathrm{NMR}$ spektrumunda 2,15 ppm de butanon yan zincirinde terminaldeki metil protonlar $13 \mathrm{H}, \mathrm{s}), 2,90$ ppm'de butanon yan zincirindeki metilen protonları $(4 \mathrm{H}, \mathrm{m})$, 3,85 ppm'de 6.konumdaki metil protonlan $(3 \mathrm{H}, \mathrm{s}), 7,2-7,8$ ppm'de aromatik protonlar $(6 \mathrm{H}, \mathrm{m})$ görülmektedir. Bileşiğin ${ }^{1} \mathrm{H}-\mathrm{NMR}$ spektrumu Şekil 1' de verilmektedir. 


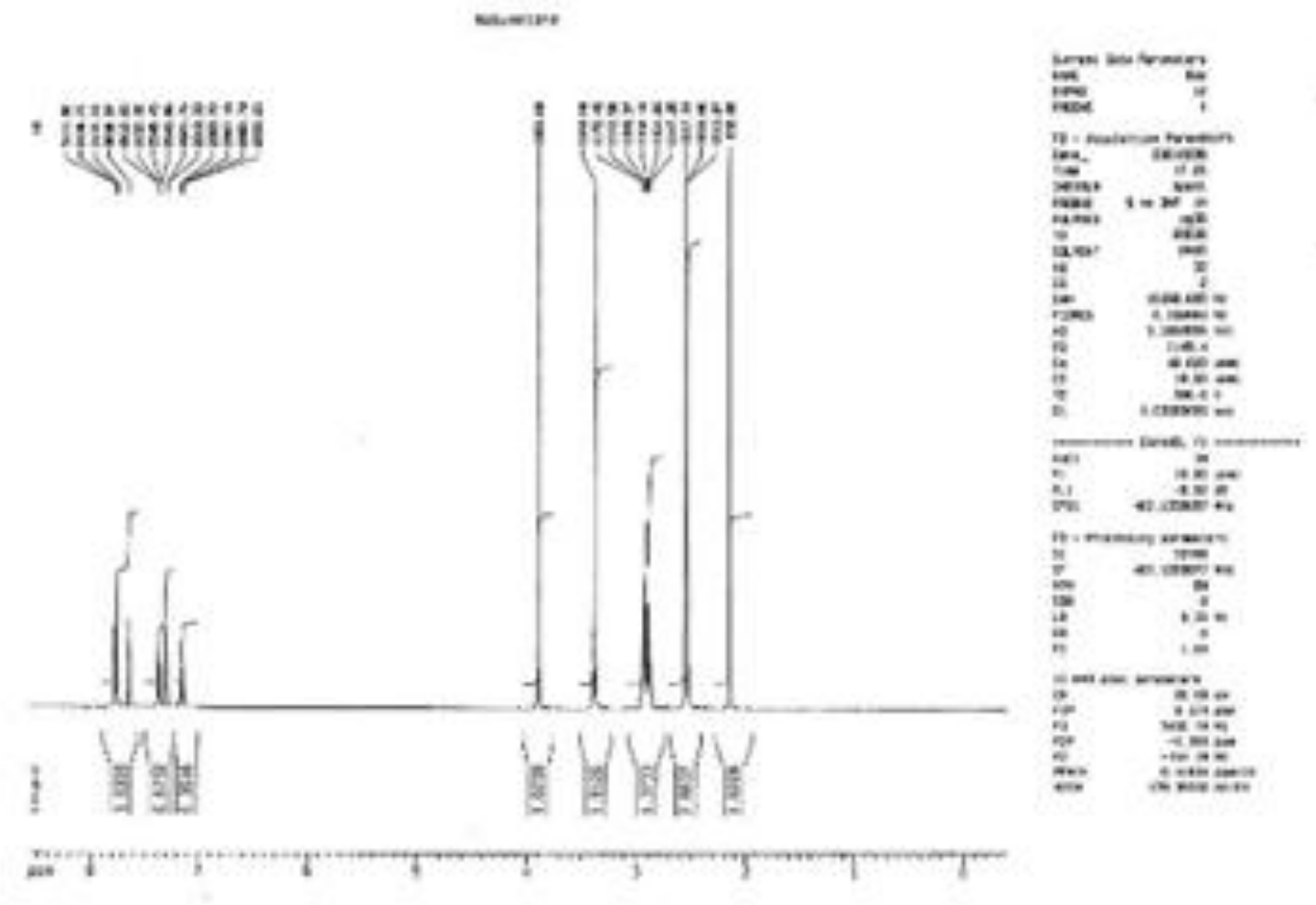

Şekil-1. Nabumetonun ${ }^{1} \mathrm{H}-\mathrm{NMR}$ Spektrumu

Benzil benzoat'ın ${ }^{1} \mathrm{H}-\mathrm{NMR}$ spektrumunda 5,35 ppm'de metilen protonları $(2 \mathrm{H}, \mathrm{s})$ ve 7,10-8,30 ppm'de ise benzen halkası protonları $(10 \mathrm{H}, \quad \mathrm{m})$ görülmektedir (Pouchert, C.J. ve ark.). Bileşiğin ${ }^{1} \mathrm{H}-\mathrm{NMR}$ spektrumu, Şekil 2'de verilmektedir. Şekil $\mathbf{3}$ ise nabumeton-benzil benzoat karışımına aittir. 


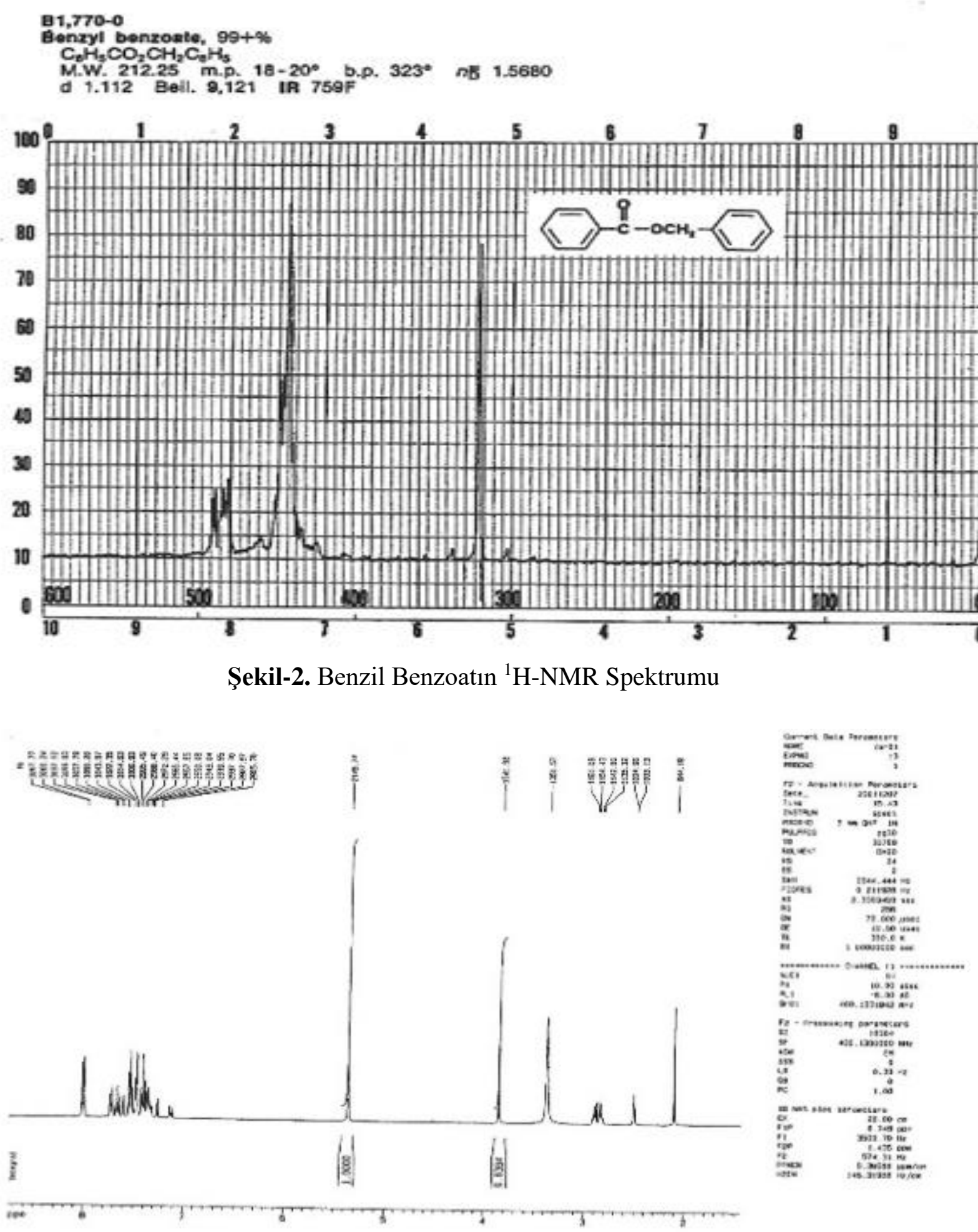

Şekil-3. Nabumeton Benzil Benzoat Karışımının ${ }^{1}$ H-NMR Spektrumu

Miktar tayininde nabumetonun 3,85 ppm'deki 6 numaralı konumundaki protonlarına ait sinyalin integral değeri ve benzil benzoatın 5,35 ppm'deki metilen protonuna ait sinyalin integral değeri 
kullanılmış ve hesaplar aşağıda verilen formüle göre yapılmıştır.

$W_{u}=W_{s} *\left(\frac{A_{u}}{A_{s}}\right) *\left(E_{u} / E_{s}\right)$

Formülde:

$\mathrm{W}_{\mathrm{u}}=$ Numunenin $\mathrm{mg}$ cinsinden miktarı (nabumeton)

$\mathrm{W}_{\mathrm{s}}=$ Standartın $\mathrm{mg}$ cinsinden miktan (benzil benzoat)

$\mathrm{A}_{\mathrm{u}}=$ Numunenin özel olarak seçilen sinyalinin integral değeri

$\mathrm{A}_{\mathrm{s}}=$ standartın özel olarak seçilen sinyalinin integral değeri

$\mathrm{E}_{\mathrm{u}}=$ Numunenin proton ekivalan ağırlığ 1 (M.A.$/$. Sinyali veren proton sayısı)

$\mathrm{E}_{\mathrm{s}}=$ Standartın proton ekivalan ağırlı̆̆ (M.Ağ./ Sinyal veren proton sayısı)

\subsubsection{Tabletlere Uygulanışı}

20 tablet hassas olarak tart1ld 1 ve havanda homojen toz haline getirildi. $10 \mathrm{mg}$ civarında nabumetona eşdeğer miktar tablet tozu tam olarak tartıldı ve üzerine yine tam olarak tartılmış 13-17 mg benzil benzoat eklendi. Karışıma 2 mL DMSO- $\mathrm{d}_{6}$ ilave edildi. Ultrasonik banyoda 10 dakika karıştırıldı ve santriftüje edildi. Üst kısımdaki berrak çözeltiden 0,4-0,5 mL alınd1 ve NMR spektrumu çekildi. Nabumeton ve benzil benzoata ait miktar tayinine esas oluşturan sinyal integrallerinden hareketle tabletlerin içerdiği nabumeton miktarı hesaplandı.

\subsection{Yüksek Basınçlı Sıvı Kromatografisi (HPLC) Miktar Tayini Yönteminin Uygulanışı}

$\mathrm{Bu}$ araştırmada, nabumetonun tabletlerdeki miktarının tayin edilebilmesi için modifiye edilmiş bir yöntem ortaya konmuştur. Bölüm 1.2.1'de verilen HPLC miktar tayini yöntemleri biyolojik sıvılarda bulunan nabumeton ve metabolitlerine aittir. Nabumeton' un farmasötik tabletlerde tespiti Al-Momani tarafindan verilmiştir (Al-Momani, F.).

Nabumetonun (4-(6-metoksi-2-naftil)butan-2-on) İngiliz Farmakopesi ile Avrupa Farmakopesinde bildirilen monograflardaki miktar tayini ile ilgili yöntemde HPLC yöntemidir (European Pharmacopoeia-2001,

British Phamacopoeia-1998).

\subsubsection{Standart Referans Çözeltinin Hazırlanışı}

$10 \mathrm{mg}$ nabumeton tam olarak tart1ld 1 ve hareketli faz ile (MeOH: $\left.\mathrm{H}_{2} \mathrm{O} ; 80: 20\right) 100$ mL'ye tamamlanarak çözüldü. 15 dakika ultrasonik su banyosunda karıştırılarak nabumetonun tamamen çözülmesi ve homojen bir çözelti oluşması sağlandı. Süre sonunda $0,45 \mu \mathrm{m}$ naylon filtreden süzüldü.

\subsubsection{Test Çözeltisinin Hazırlanışı}

20 tablet tam olarak tartıldı ve havanda ince toz haline getirildi. Toz numuneden $10 \mathrm{mg}$ nabumetona tekabül eden miktar 100 mL'lik balonjoje içine alınd 1 ve "Standart Referans Çözeltinin Hazırlanışı" kısmında anlatılan işlemler aynen uygulandi. 


\subsubsection{Deneyin Yapılıșı}

Hazırlanan standart referans çözeltisinden sirasiyla 0,$5 ; 1,0 ; 2,0 ; 3,0 ; 4,0$ ve $5,0 \mathrm{~mL}$ alındı ve her biri ayrı ayrı $10 \mathrm{~mL}$ ye hareketli faz ile tamamland $15 ; 10 ; 20 ; 30$; 40 ve $50 \mu \mathrm{g} / \mathrm{mL})$. Bu çözeltilerin her birinden $20 \mu \mathrm{L}$ enjekte edilerek 4,48 dakikada görülen nabumeton pikinin alanları ayrı ayrı bulundu. Alan ile $\mu \mathrm{g} / \mathrm{mL}$ (ppm) cinsinden konsantrasyon arasındaki doğrusal ilişki grafik halinde çizildi ve doğru denklemi ile bu denklemin korelasyon katsayısı $\left(\mathrm{r}^{2}\right)$ bulundu. Sonuçlar Şekil 4 'de verilmektedir.

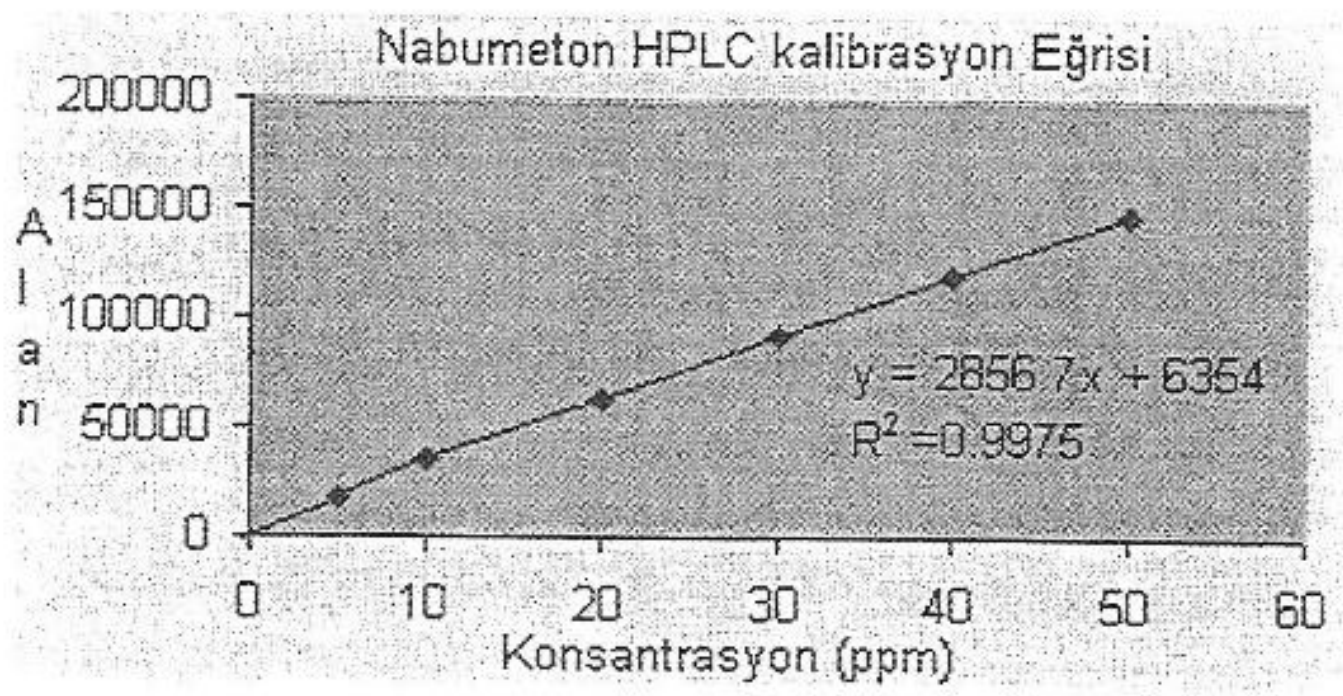

Şekil-4. Nabumetonun HPLC Kalibrasyon Eğrisi

Tablet çözeltisinden $0,5 \mathrm{~mL}$ ve $1,0 \mathrm{~mL}$ ayr ayrı alındı, hareketli faz ile 10'ar mL'ye tamamland 1 ve enjekte edilerek 4,48 dakikada görülen nabumeton pikinin alanları bulundu. Çapı 4,6 mm, uzunluğu $15 \mathrm{~cm}$ olan $\mathrm{C}_{18}$ kolon, hareketli faz metanol:su (80:20), akış hızı $1 \mathrm{~mL} / \mathrm{dk}$, detektör DAD detektör, kolon sicaklığ 25 ${ }^{\circ} \mathrm{C}$ ve enjeksiyon hacmi olarak $20 \mu \mathrm{L}$ 'nin kullanıldığı kromatogafik şartlarda alınan nabumetonun kromatogramı Şekil 5'de verilmektedir.
Bulunan değerler standart referans çözeltisi için hesaplanan doğru denklemine konularak tablet içindeki nabumetonun miktarı bulundu. Ayrıca 230, 260 ve 332 nm'deki nabumeton kromatogamlar1 alınarak minimum deteksiyon limiti (LOD) tespit edildi. $\mathrm{Bu}$ dalga boylarına ait sonuçların değerlendirmeleri "Bulgular" kısmında verilmiştir. 


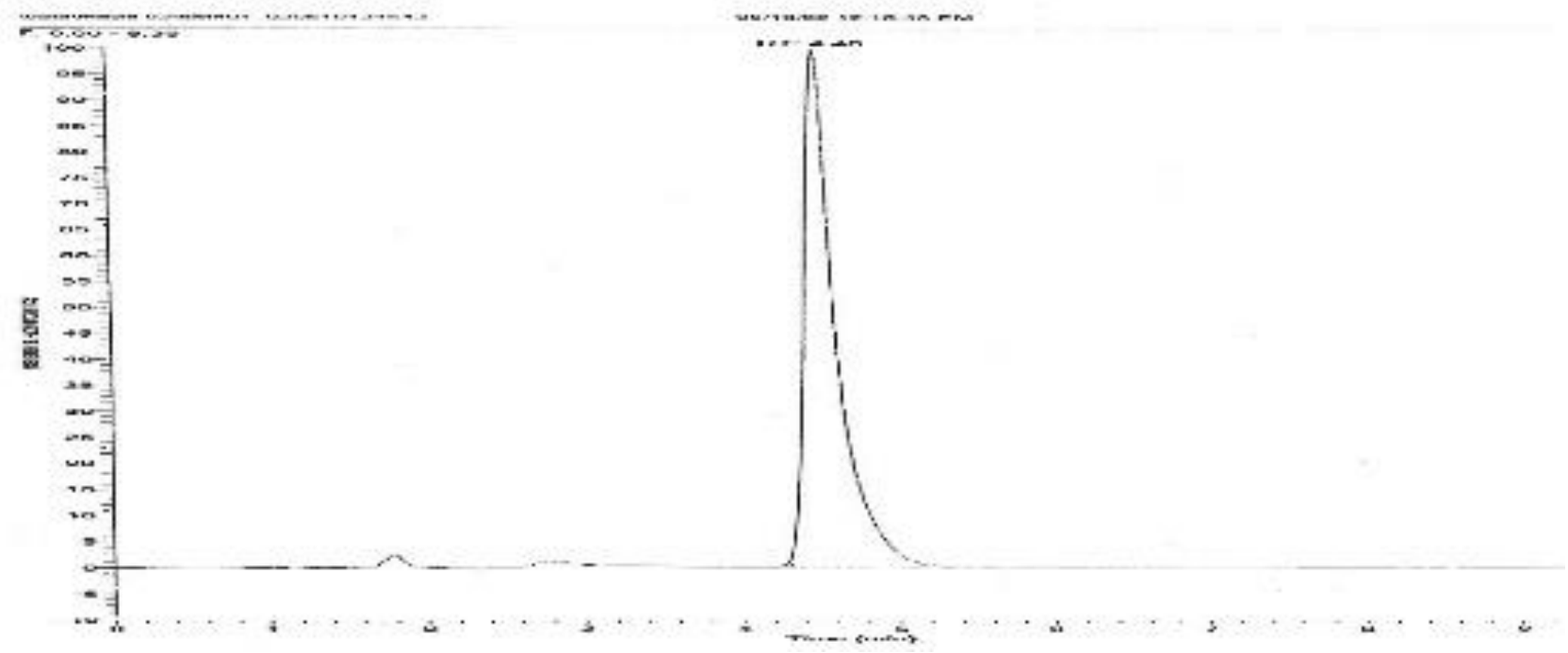

Şekil-5. Nabumetonun HPLC Kromatogram1

Bulunan alan değerleri standart referans çözeltisindeki benzer uygulamanın alan değerleri ile aşağıda verilen denklem üzerine konularak tekrar hesaplandı.

$$
C_{\text {num }}=C_{s t} \times A_{\text {num }} / A_{s t}
$$

$\mathrm{C}_{\text {num: }}$ Nabumeton tablet numunesinin konsantrasyonu

$\mathrm{C}_{\mathrm{st}}$ : Nabumeton referans standardının konsantrasyonu

$\mathrm{A}_{\text {num: }}$ Nabumeton tablet numunesinin alan değeri

$\mathrm{A}_{\text {st: }}$ : Nabumeton referans standartının alan değeri

\subsection{Yüksek Performanslı İnce Tabaka Kromatografisi (HPTLC) Miktar Tayini Yönteminin Uygulanışı}

$\mathrm{Bu}$ araştırmada, nabumetonun tabletlerdeki miktarının tayin edilebilmesi için modifiye edilmiş bir yöntem ortaya konmuştur. Bölüm 1.2.4'de anlatılan araştırmalar yüksek performanslı ince tabaka kromatografi cihazı kullanılarak yapılan çalışmalara aittir. İlacı üreten firma tarafından yapılan çalışmada ise İTK yöntemi nabumetonun parçalanma ürünlerinin tayini için verilmiştir. $\mathrm{Bu}$ araştırmada HPTLC cihazı kullanılarak şartlar modifiye edilmiş, müstahzarlara uygulanmış ve nabumetonun yüzde miktarının tayini yapılmıştır. Firma spesifikasyonu olarak bildirilen parçalanma ürünlerinin tayininde elüent olarak kloroform kullanıldığında düzgün bir sürüklenme olmamış sürüklenmeyi düzeltmek için ortama metanol ilavesi yapılmıştır.

\section{Gereç:}

- İTK tank1

- $20 \times 20 \mathrm{~cm}$, floresan indikatörlü $\mathrm{F}_{254}$ silikajel ile $0,25 \mathrm{~mm}$ incelikte kapl1 plakalar

- Kisa dalga boyunda UV lambasi

- Uygun cam malzeme

\section{Materyal:}

Eluent: Kloroform: Metanol ( 97: 3 ) 
Test çözeltileri: Standart nabumetondan 10 mg civarında tam olarak tartılarak $200 \mathrm{~mL}$ metanolde çözüldü. Nabumeton içeren tetkik edilecek numuneden de $10 \mathrm{mg}$ etken maddeye eşdeğer tablet tozu tam olarak tartılarak $200 \mathrm{~mL}$ metanolde ultrasonik banyoda 15 dakika bekletilerek çözünmesi sağlandı. Süre sonunda numuneler 0,45 $\mu$ 'luk naylon filtreden süzülerek numune çözeltisi hazırlandı.

\section{İşlem:}

ITK plakasina standart nabumeton çözeltisinden $15,10,8,5,4,3,2$ ve 1 mikrolitre tatbik edildi. Numune çözeltisinden de 5 mikrolitrelik tatbikler yapıld1. Plaka önceden dengeye getirilmiş tanka yerleştirildi ve developman çözeltisi $15 \mathrm{~cm}$ yüksekliğe erişinceye kadar develope edildi. Plaka çıkarılarak oda sicaklığında kuruyuncaya kadar bekletildi. Tarayıc1 230 nm'ye ayarlanarak standart ve numune lekelerine karşılık gelen alan ve yükseklik değerlerinden yüzde nabumeton miktarı tespit edildi. Alan ile tatbik edilen hacim cinsinden konsantrasyon arasindaki doğrusal ilişki grafik halinde çizildi ve doğru denklemi ile bu denklemin korelasyon katsayısı bulundu. Sonuçlar Şekil 6 'da verilmektedir.

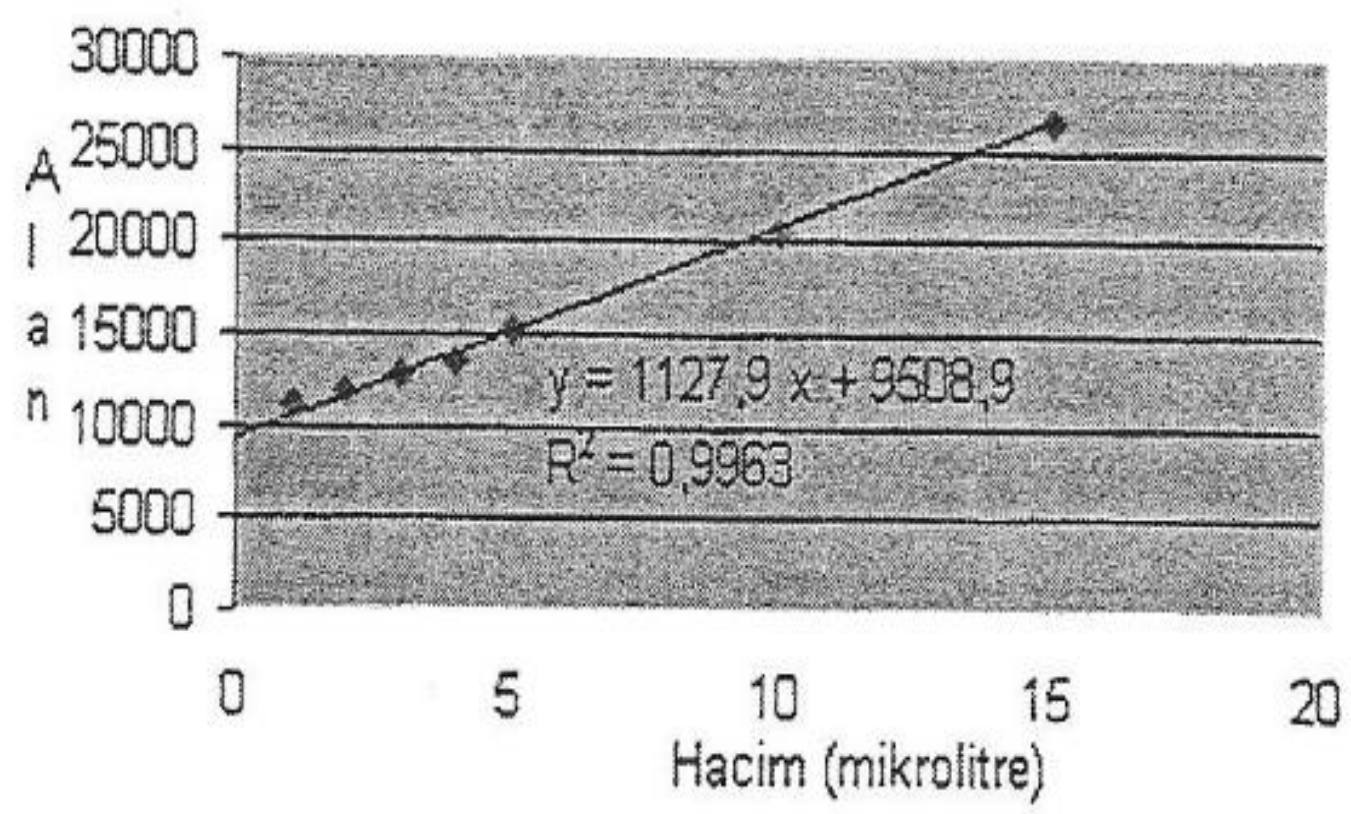

Şekil-6. Nabumetonun HPTLC Kalibrasyon Eğrisi 
Yukarıda verilen kromatografik şartlarda kromatogramı Şekil 7'de verilmektedir. alınan nabumetonun HPTLC

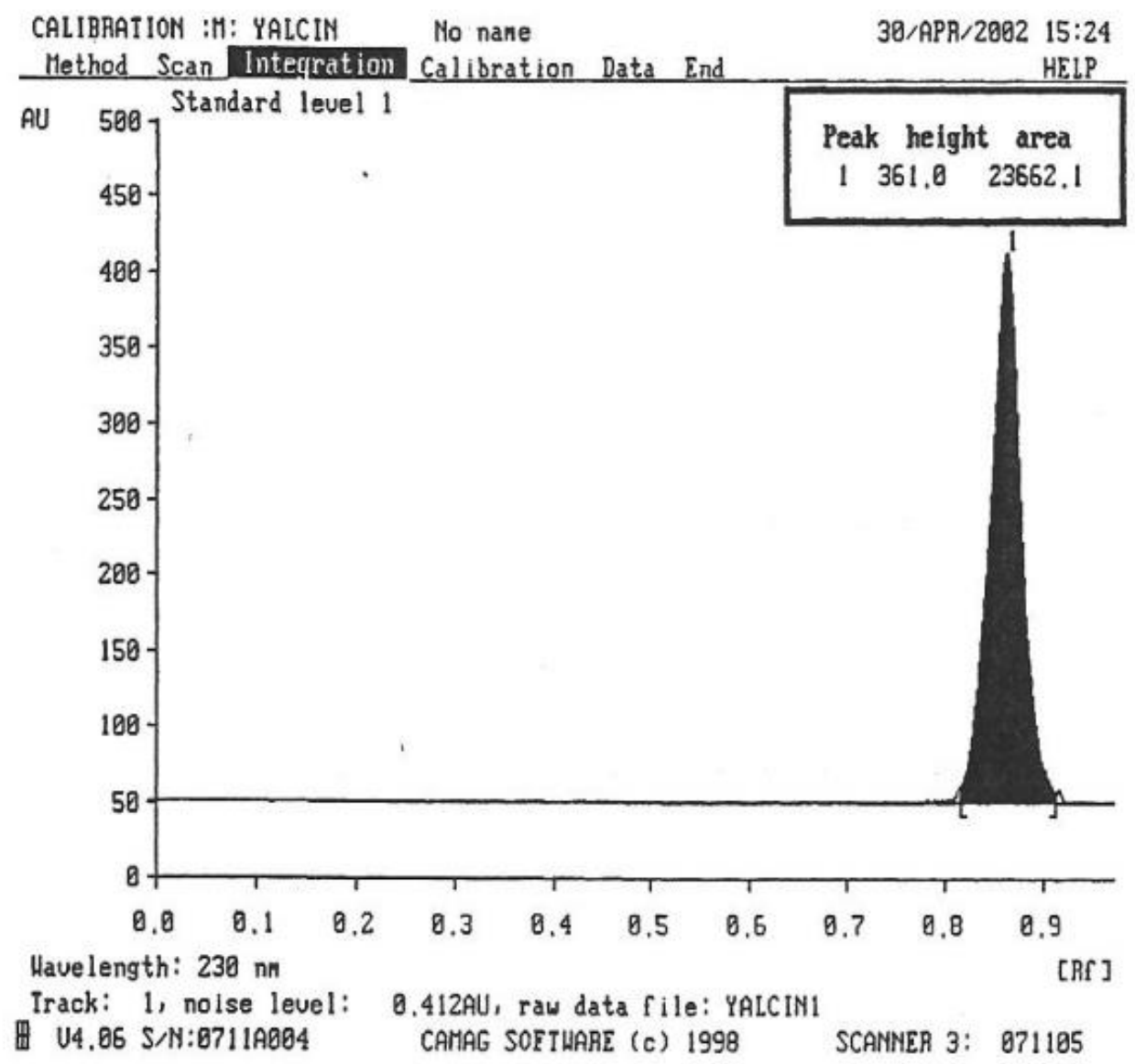

Şekil-7. Nabumetonun HPTLC Kromatagramı

2.7. Sıvı Kromatograf/Kütle Spektroskopisi (LC/MS) Miktar Tayini Yöntemi

LC/MS yönteminde ESI modu kullanılmıştır. Bu iyonizasyon yönteminde cihazda iki tip optimizasyon yapılması gerekmektedir. Bunlar sirasiyla;

a- ESI Modu seçimi

b- Cone Voltaj optimizasyonu

$\mathrm{Bu}$ iki optimizasyon çalışma konusunu oluşturan nabumeton için araştırılmış ve deneysel olarak yapılan çalışmalar sonucu bulunmuştur. $\mathrm{Bu}$ optimizasyon işlemleri aşağıda açıklanmaktadır.

\subsubsection{ESI Modu Seçimi}

$\mathrm{Bu}$ yöntemlerle yapılan miktar tayinlerde Elektrospray (ES) tekniği kullanılmıştır. ES tekniğinde pozitif veya negatif iyon modu analizi yapılacak bileşiğin molekül yapısına göre seçilmektedir. 
Nabumeton yapisina göre kolayca bir proton bağlayabileceği için $\mathrm{ES}^{+}$iyon modu seçilmiştir. Proton bağlanması ile ilgili reaksiyon denklemi aşağıda verilmektedir.
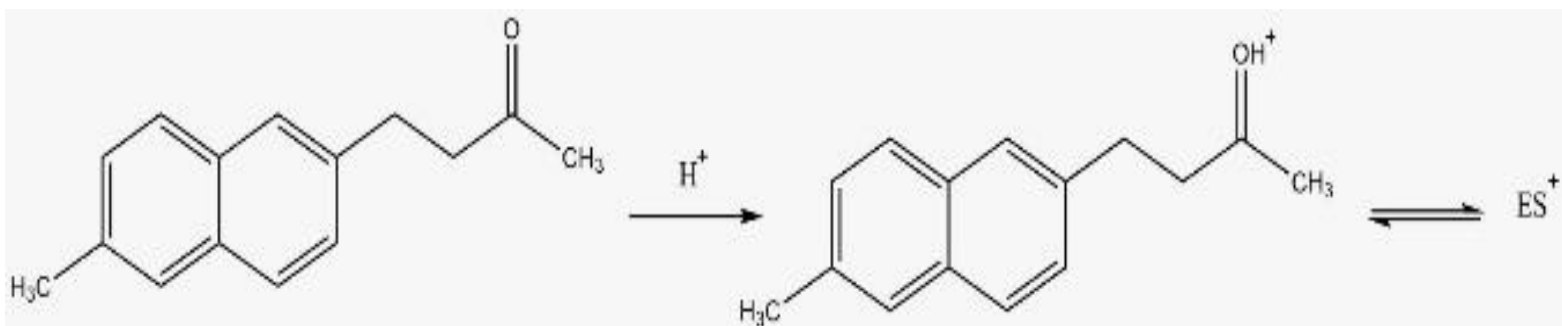

Şekil-8. Nabumeton Proton Bağlanması İle İlgili Reaksiyon Denklemi

$\mathrm{ES}+$ iyon modunun seçilmesi sırasında işlem deneysel olarak da yapılmış ve her iki modun uygulanması ile alınan spektrumlar Şekil 9'da verilmektedir.
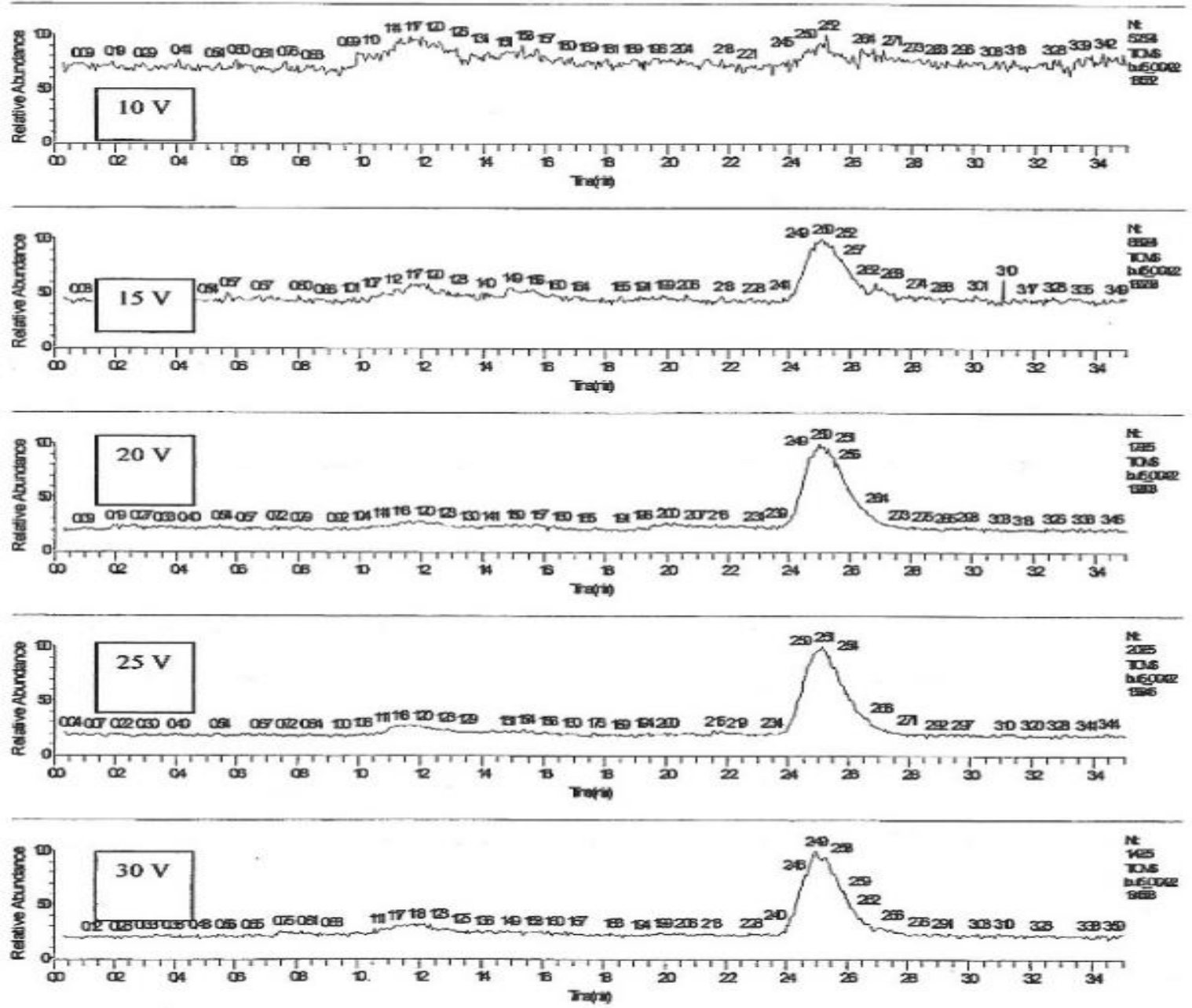

Şekil-9. Nabumeton $\mathrm{ES}^{+}$ve ES${ }^{-}$LC/MS Spektrumu 
Spektrumlarda görüleceği üzere $\mathrm{ES}^{+}$ modunda moleküler iyon şiddeti $\left(5,92 \mathrm{e}^{7}\right)$, belirgin olmayan $\mathrm{ES}^{-}$modundaki moleküler iyon şiddetine göre çok daha yüksektir. $\mathrm{Bu}$ sebeple miktar tayini uygulamasında $\mathrm{ES}^{+}$modu seçilmiştir.

\subsubsection{Cone Voltaj (CV) Optimizasyonu}

ES modunda iyonizasyonu sağlayan ve cone voltaj olarak isimlendirilen voltajin şiddeti önemlidir. CV 'in şiddeti fragmantların oluşumunu etkilemektedir. $\mathrm{CV}$ arttıkça fragmantasyon artmaktadır. $\mathrm{Bu}$ sebeple kütle spektroskopisi kullanılarak yapılan miktar tayinlerinde moleküler iyonun en şiddetli dolayısıyla parçalanmaların en az olduğu voltaj seçilmektedir.

Nabumeton için CV seçimi 10-70eV arasında uygulanmış ve moleküler iyona $\left(\mathrm{M}^{+}+1=229\right)$ ait spektrumlar Şekil 10 'da verilmektedir. Spektrumdan anlaşılacağ gibi en şiddetli pik $\left(2,02 \mathrm{e}^{5}\right) 25$ eV'da elde edilmektedir. $\mathrm{Bu}$ sebeple miktar tayininde $\mathrm{CV}=25 \quad \mathrm{eV}$ olarak seçilmiştir.
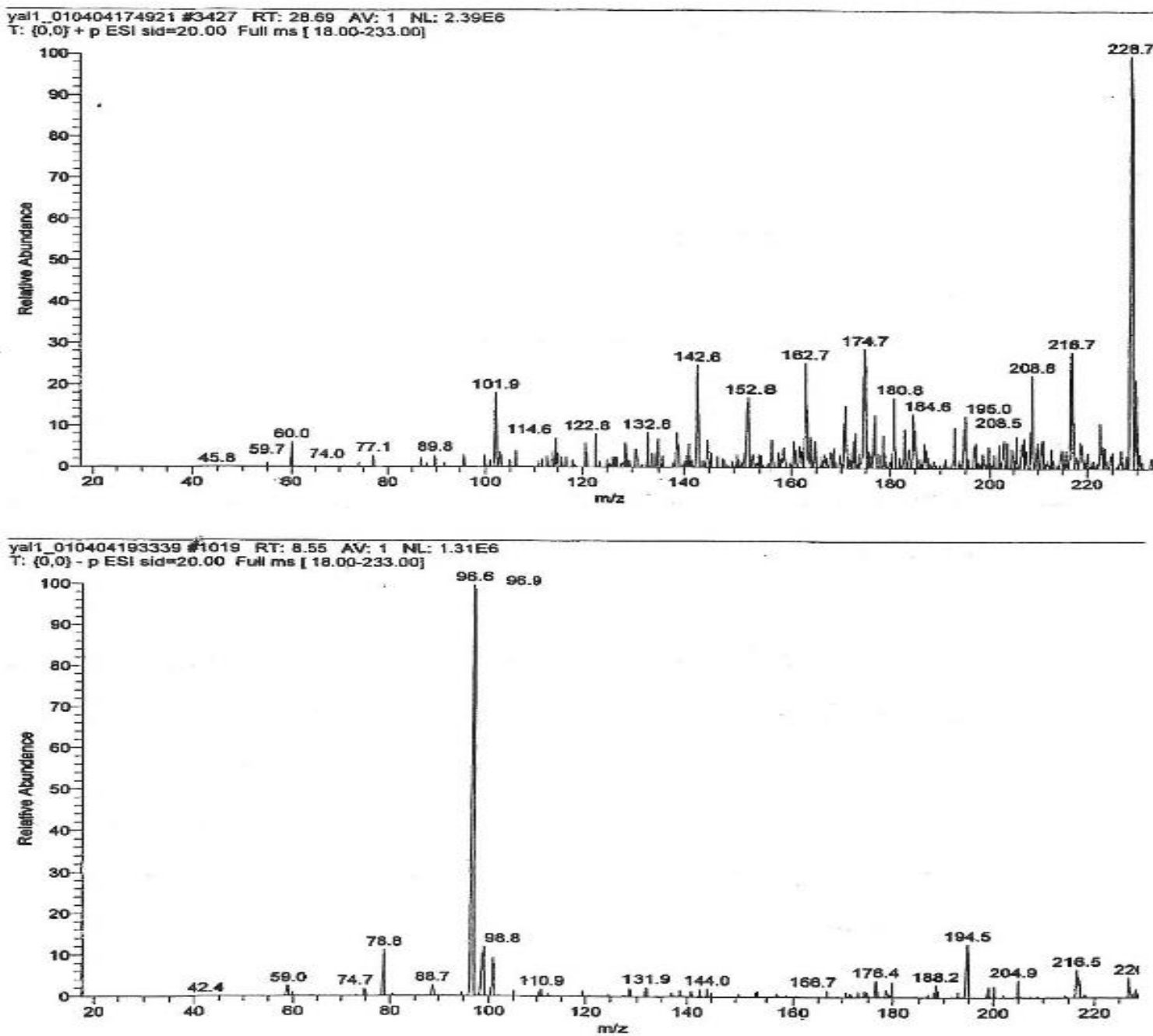

Şekil-10. Nabumetonun LC/MS Spektrumunda Cone Voltaj Optimizasyonu 
2.8.1. Sıvı Kromatograf / Kütle Spektroskopisi (LC/MS) Miktar Tayini Yönteminin Uygulanışı

LC-MS yöntemi ile yapılan miktar tayini çalışmalarında SIM (Single-İonMonitoriing) data elde etme modu kullanılmaktadır. Bu mod, özellikle bilinen veya hedeflenen bileşiklerin teşhisinde ve kantitatif analizlerinde spektrumdaki tüm piklerin tarama akuzisyonu yerine seçilen tek bir pikin akuzisyonunun daha hassas alınabilmesi için kullanılmaktadır. Genellikle moleküler iyon seçilen pik olmakta ve kütle analizörü sadece bu iyon için tarama yapıp Toplam İyon Kromatogram (TIC) vermektedir. $\mathrm{Bu}$ şekilde kütle spektrometresi hassas ve seçici bir detektör olarak işlem yapmaktadır. Sadece bir tek iyonun seçilmesi hassasiyeti arttırmaktadır.

Analizi yapılacak numunede birden fazla bileşik var ise bileşiklerin kromatogramdaki alıkonma zamanlarına ve oluşan iyonun molekül ağırlığına göre ayrı ayrı kromatogramları alınarak her birinin analizi yapılabilmektedir. Ancak, bu araştırmada kromatografi kolonu kullanılma sebebi, ortamdan gelebilecek safsızlıkları uzaklaştırmak ve ayrıca pik biçimlerinin daha düzgün elde edilmesidir.

\section{Analizin Yapılışı}

\section{HPLC Şartları:}

- HPLC:

ThemoQuest SpektraSystem S1v1 Kromatogafi Sistemi
- Kolon: CR Phenomenex, 50 x 4,6 $\mathrm{mm}, 3 \mu \mathrm{m}$

- Mobil Faz: Su: MeOH (20:80), izokratik sistem

- Kolon Sıcaklığı: $25^{0} \mathrm{C}$

- Akış Hızı: 0,4 mL/dk

Kütle Spektrometresi Şartları:

- LC/MS Cihazı: ThermoQuest Finnigan AQA Kütle Spektrometresi

- Cone Voltage: $25 \mathrm{eV}$

- Polarity: $\mathrm{ES}^{+}$

- Dwell Time: 0,37

- Points/sec: 2,70

- Probe $(\mathbf{k V}): 3,00$

- Probe CC): 3,00

- $\quad \operatorname{RF} \operatorname{Lens}(\mathbf{V}): 0,2$

- LM: 12,5

- HM Res: 12,5

- I Energy: 1,0

\section{Miktar Tayininin Yapılışı:}

Hazırlanan 100 pg/ $\mu$ L'lik stok nabumeton çözeltisinden $3,4,5,10,20,25,30,40,50$ ve $60 \mu \mathrm{L}$ otomatik enjektörle tatbik edildi. $\mathrm{Bu}$ enjeksiyonların SIM modunda alınan ve moleküler iyona (229) ait TIC'lar Şekil 11'de gösterilmektedir. 


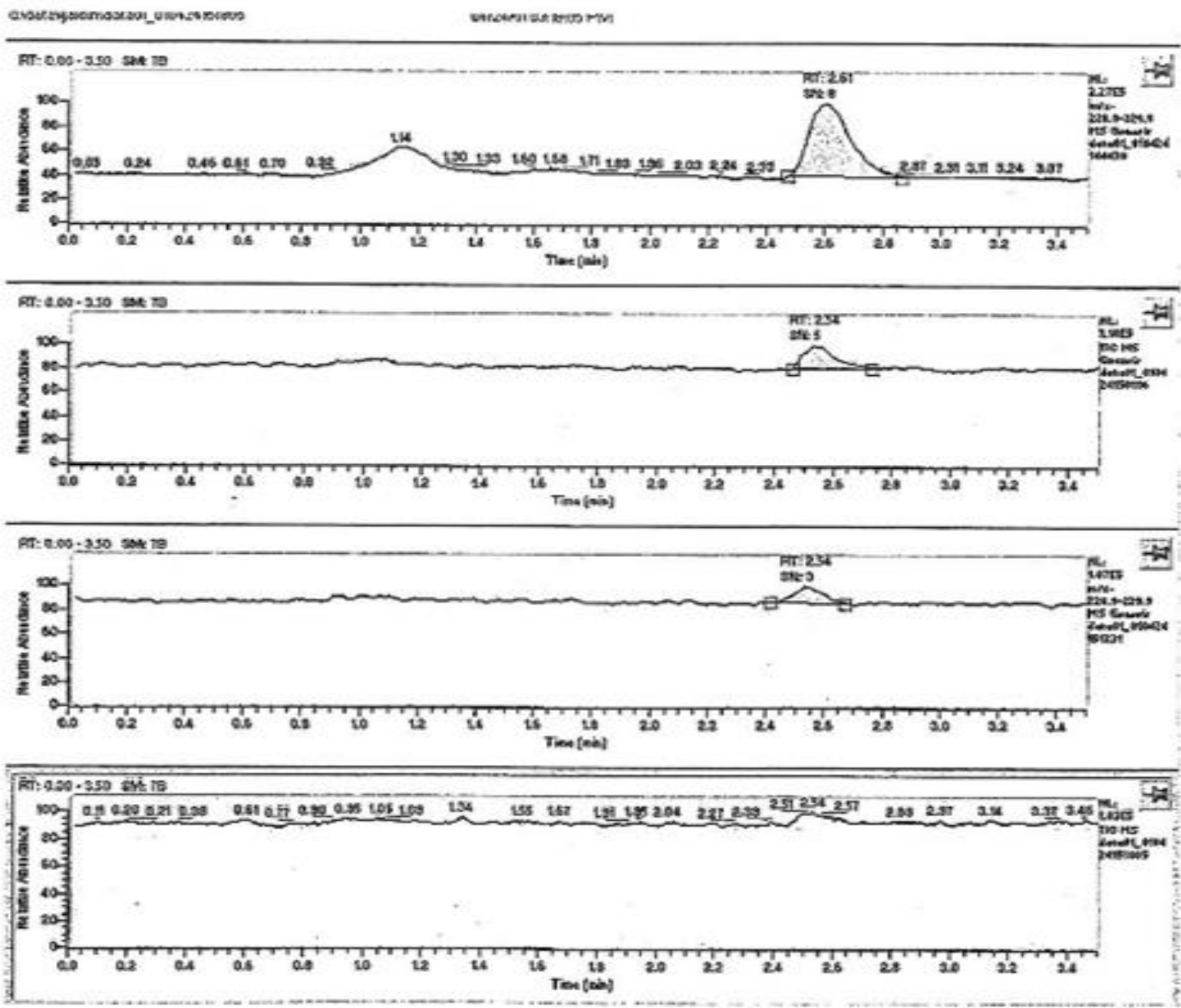

Şekil-11. Nabumetonun SIM modunda alınan ve moleküler iyona (229) ait TIC'ları

Şekilden görüleceği gibi $3 \mu$ L'Iik uygulamada nabumetonun iyonu görülmemektedir. $4 \mu \mathrm{L}$ enjeksiyonda ise iyon belirgin durumdadir. Yapılan çalışmalarda nabumetona ait iyonun 4 $\mu$ L'lik enjeksiyon ile teşhis yapılabildiği tespit edilmiştir. $\mathrm{Bu}$ çalışmada $4 \mu \mathrm{L}$ enjeksiyona denk gelen nabumeton ihtiva eden limite kadar teşhis, $20 \mu \mathrm{L}$ enjeksiyona denk gelen nabumeton içeren limite kadar miktar tayininin gerçekleşebileceği bulunmuştur.

\section{Standart Nabumeton Eğrisinin Oluşturulması}

$100 \mathrm{pg} / \mu \mathrm{L}$ konsantrasyonunda hazırlanan nabumeton çözeltisinden $3 ; 4 ; 5$;

$10 ; 20 ; 30 ; 40 ; 50$ ve $60 \mu \mathrm{L}$ çözeltiler otomatik örnekleyici aracılığıyla ayrı ayrı enjekte edildi.

Her çözelti için m/z 229'da görülen iyonun $(\mathrm{M}+1)^{+}$toplam iyon kromatogramı alındı. Kromatogramın alan değerleri cihaz tarafından otomatik olarak hesaplandi. 
Bulunan değerler enjekte edilen çözelti miktarına karşılık olacak şekilde kalibrasyon eğrisi oluşturuldu. Oluşturulan kalibrasyon eğrisi, doğru denklemi, ve denklemin korelasyon katsayısı Şekil 12'de verilmektedir.

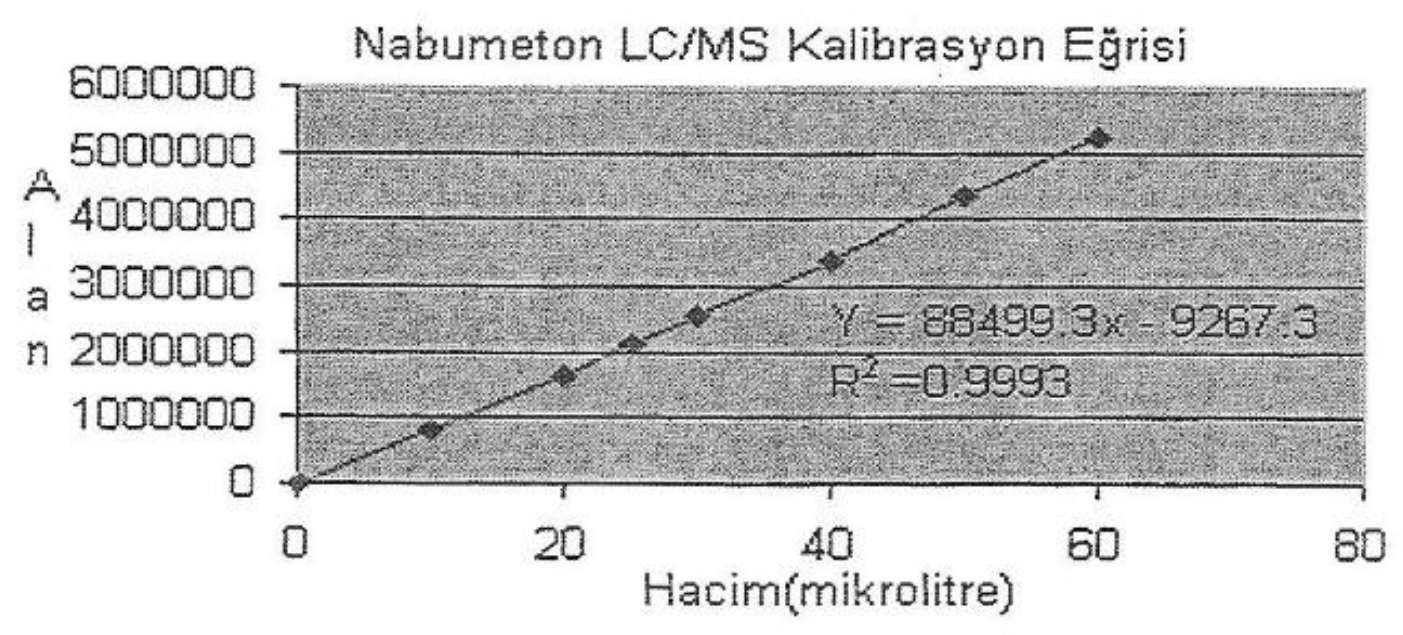

Şekil-12. Nabumetonun LC-MS (SIM) Kalibrasyon eğrisi

\section{Ticari Tablet Miktar Tayini}

20 tablet tam olarak tartıld, ince toz haline getirildi. Metanol:su (80:20, v/v) içinde $100 \mathrm{pg} / \mu \mathrm{L}$ lik çözeltisi hazırlandı. 30, 40 ve $50 \mu \mathrm{L}$ enjekte edildi. Yukarıda anlatılan şekilde moleküler iyon $(\mathrm{M}+1)^{+}$pikinin TIC'1 alınd. Bulunan alan değerlerin standart nabumeton kalibrasyon eğrisine konuldu ve tablet içinde bulunan nabumeton miktarı tespit edildi.

\section{Bulgular}

\subsection{Standart Nabumetonun Tanıma Ve Saflık Analiz Sonuçları 3.1.1. Ergime Noktası}

Yapılan ergime noktası tayininde nabumeton standartının ergime noktası 80 $81{ }^{\circ} \mathrm{C}$ bulunmuştur. $\mathrm{Bu}$ değer literatürde verilen değer ile $(80 \mathrm{C}$ ) aynıdır (Goudie, A.C. ve ark.).

\subsubsection{IR Spektrumu}

Standart nabumetonun $\mathrm{KBr}$ diski hazırlanarak IR spektrumu alınmış ve nabumetonun IR spektrumu Şekil 13 'de verilmiştir. 


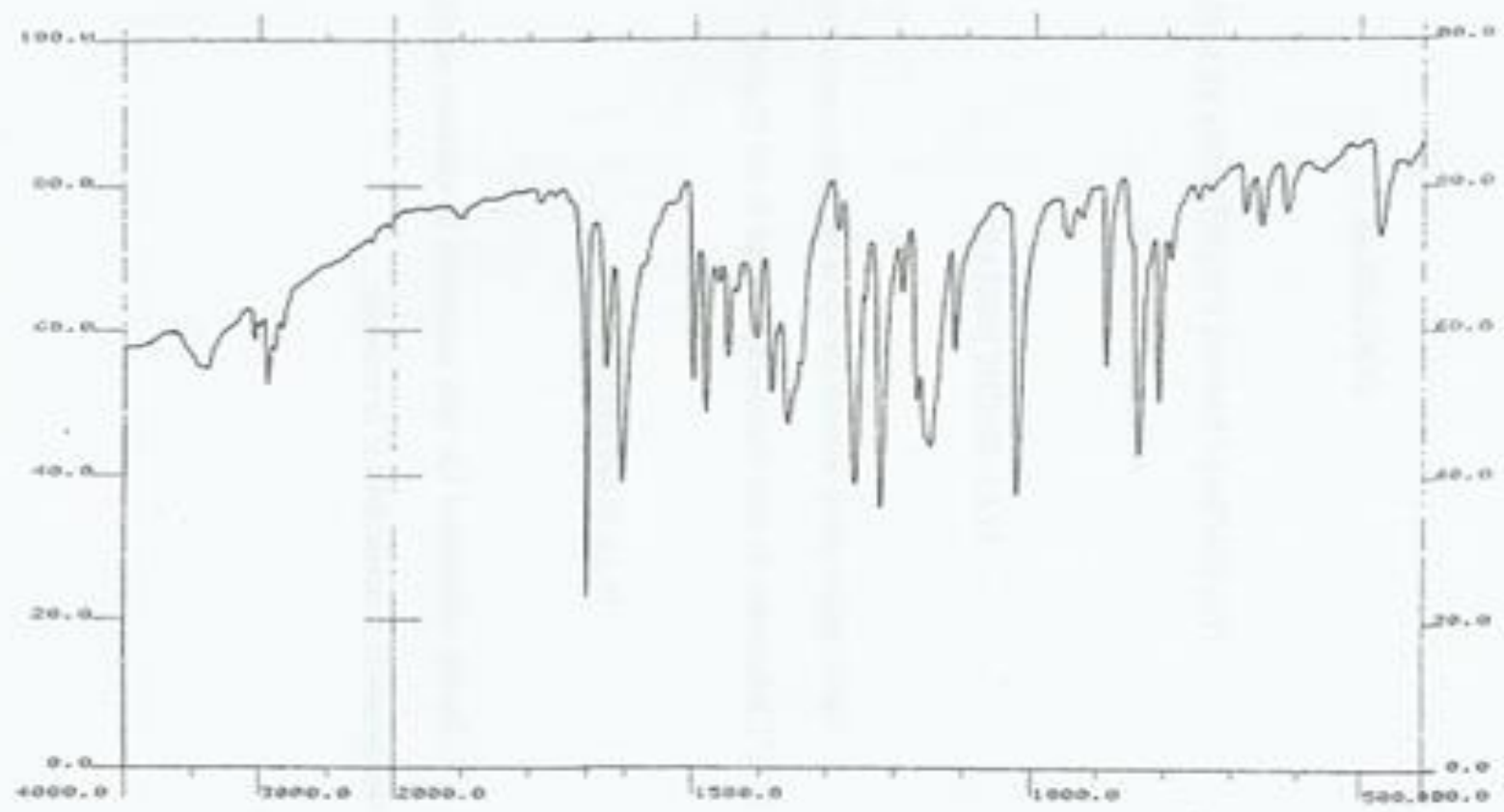

Şekil-13. Nabumetonun IR Spektrumu

\subsubsection{Kütle Sprektrumu}

Standart nabumetonun kütle spektrumu için kütüphane taraması yapılmıştır. Şekil
14 standart nabumeton bileşiğinin Wiley tarafindan verilen kütle spektrumunu ve cihaz üzerinde bulunan kütüphane tarama sonuçlarını vermektedir.

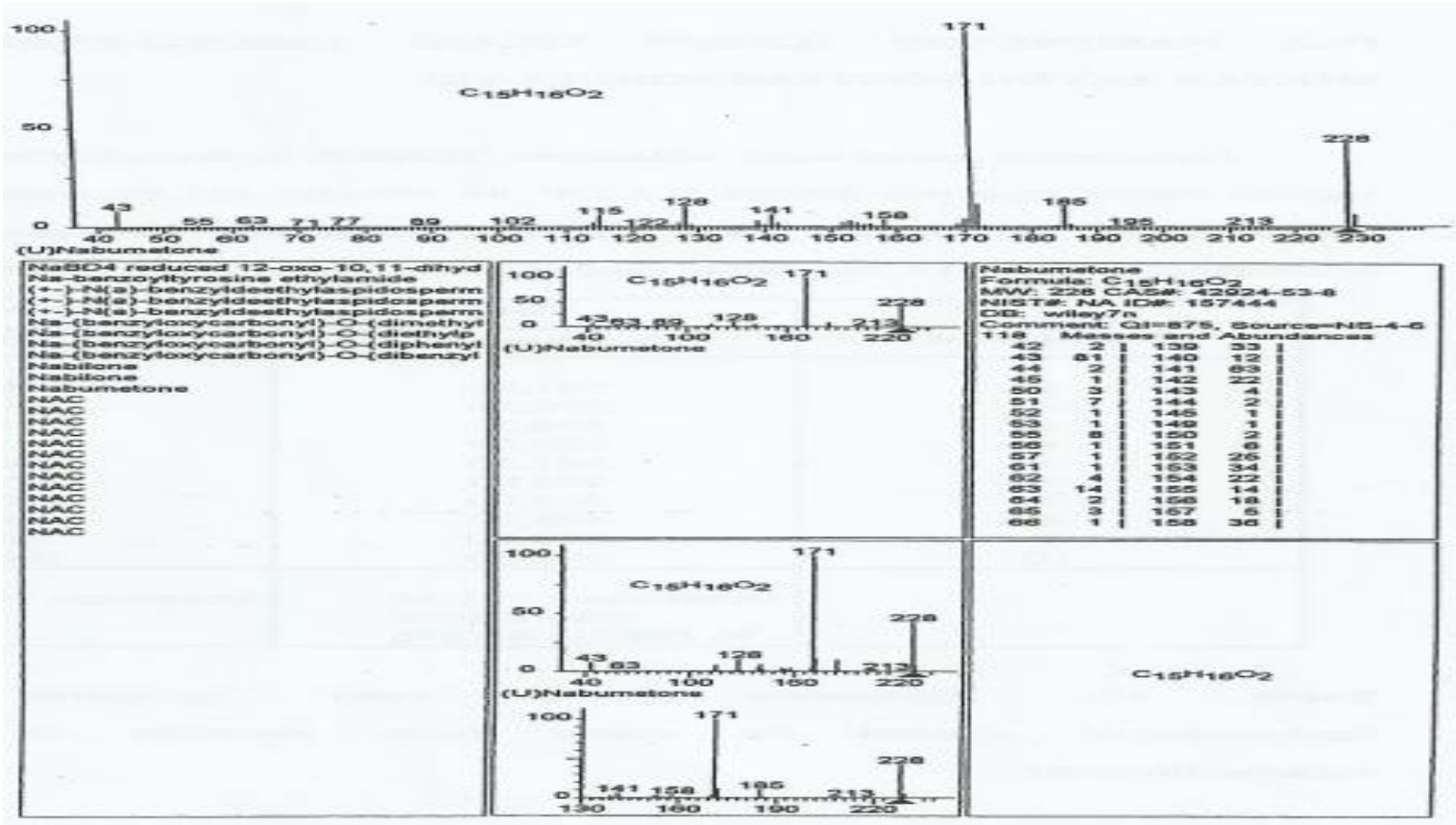

Şekil-14. Nabumetonun Kütle Spektrumu ve

Kütüphane Taraması 


\subsection{Nabumeton İçeren Ticari} Tabletlerde ${ }^{1}$ H-NMR Miktar Tayini Yöntemi Sonuçları

Nabumeton içeren ticari tabletlerde ${ }^{1} \mathrm{H}$ NMR Spektroskopisi Yöntemi ile yapılan miktar tayininde Bölüm 2.4.1'de anlatılan yol izlenmiştir. ${ }^{1} \mathrm{H}$-NMR Spektroskopisi ile yapılan miktar tayininde yöntemin tekrarlanabilirliği de incelenmiştir. Tablo 2, bu şekilde yapılan deneyin sonuçlarını vermektedir.

Tablo-2. Nabumeton İçeren Ticari Tabletlerde ${ }^{1} \mathrm{H}$-NMR Yöntemi İle Miktar Tayini Sonuçları ve İstatiksel Değerlendirmeleri

\begin{tabular}{|c|c|c|}
\hline \multirow{2}{*}{$\begin{array}{c}\text { Numune } \\
\text { No }\end{array}$} & \multicolumn{2}{|c|}{ Relifex Film Tablet, 500mg. } \\
\hline & Bulunan mg & Bulunan \% \\
\hline 1 & 501,00 & 100,20 \\
\hline 2 & 500,50 & 100,10 \\
\hline 3 & 506,50 & 100,30 \\
\hline 4 & 509,00 & 101,80 \\
\hline 5 & 501,50 & 100,30 \\
\hline 6 & 496,00 & 99,20 \\
\hline 7 & 502,00 & 100,40 \\
\hline 8 & 498,00 & 99,60 \\
\hline 9 & 499,50 & 99,90 \\
\hline 10 & 502,50 & 100,50 \\
\hline & $\begin{array}{r}\text { Ortalama: } 501,65 \\
\text { SS: } 3,8009 \\
\%(B S S): 0,7576\end{array}$ & $\begin{array}{l}\text { Ortalama\%: } \\
100,33\end{array}$ \\
\hline
\end{tabular}

\subsection{Nabumeton İçeren Ticari Tabletlerde HPLC Miktar Tayini Yöntemi Sonuçları}

Nabumeton içeren ticari tabletlerde HPLC yöntemi ile yapılan miktar tayininde Bölüm 2.5' de anlatılan yol izlenmiştir. Yönteme ait sonuçlar Tablo 3 ' de verilmektedir.
Tablo-3. Nabumeton İçeren Ticari Tabletlerde HPLC Miktar Tayini Sonuçları ve İstatistiksel Değerlendirmeleri

\begin{tabular}{|c|c|c|}
\hline \multirow{2}{*}{$\begin{array}{c}\text { Numune } \\
\text { No }\end{array}$} & \multicolumn{2}{|c|}{ Relifex Film Tablet, 500mg. } \\
\cline { 2 - 3 } & Bulunan mg & Bulunan \% \\
\hline 1 & 496,25 & 99,25 \\
\hline 2 & 505,50 & 101,10 \\
\hline 3 & 509,50 & 101,90 \\
\hline 4 & 504,00 & 100,80 \\
\hline 5 & 494,50 & 98,90 \\
\hline 6 & 500,50 & 100,10 \\
\hline 7 & 497,50 & 99,50 \\
\hline 8 & 496,00 & 99,20 \\
\hline 9 & 498,50 & 99,70 \\
\hline 10 & 501,50 & 100,30 \\
\hline & Ortalama: 505,35 & Ortalama\%: \\
& SS: 2,6462 & 101,07 \\
\hline
\end{tabular}

Yöntemin uygulanmasında, $50 \mathrm{ng} / \mu \mathrm{L}$ 'deki çözeltiden otomatik örnekleyici ile $8,5,4$, 3,2 ve $1 \mu$ L'lik enjeksiyonlar yapılarak $230 \mathrm{~nm}, 260 \mathrm{~nm}$ ve $332 \mathrm{~nm}$ 'deki S/N değerleri kaydedilmiştir. Sonuçlar Tablo 4'de verilmiştir.

Tablo 4'den anlaşılacağı üzere uygun dalga boyu daha alt limitlere inme bakımından $230 \mathrm{~nm}$ olarak tespit edilmiştir.

Tablo-4: HPLC Yöntemine Ait S/N Sonuçları.

\begin{tabular}{|c|c|c|c|}
\hline \multirow{2}{*}{ Enjeksiyon $(\mu \mathrm{L})$} & \multicolumn{3}{|c|}{ S/N Değeri } \\
\cline { 2 - 4 } & $\lambda: 230 \mathrm{~nm}$ & $\lambda: 260 \mathrm{~nm}$ & $\lambda: 332 \mathrm{~nm}$ \\
\hline 8 & 278 & 21 & 13 \\
\hline 5 & 83 & 9 & 7 \\
\hline 4 & 78 & 8 & 3 \\
\hline 3 & 30 & 2 & - \\
\hline 2 & 11 & - & - \\
\hline 1 & 2 & - & - \\
\hline
\end{tabular}

Deneyde nabumeton için $230 \mathrm{~nm}$ 'de 100 $\mathrm{ng} / 2 \mu \mathrm{L}$ limitine kadar miktar tayininin gerçekleşebileceği bulunmuştur. 
3.4. Nabumeton İçeren Ticari Tabletlerde LC/MS Yöntemi Sonuçları 3.4.1. Nabumeton İçeren Tabletlerde LS/MS Miktar Tayini Yöntemi Sonuçları

Nabumeton içeren ticari tabletlerde LC/MS yöntemiyle yapılan miktar tayininde Bölüm 2.7' de anlatılan yol izlenmiştir. Sonuçlar Tablo 5'de verilmektedir.

Tablo-5: Nabumeton İçeren Ticari Tabletlerde LC/MS Yöntemi İle Miktar Tayini Sonuçları ve İstatistiksel Değerlendirmeleri

\begin{tabular}{|c|c|c|}
\hline \multirow{2}{*}{$\begin{array}{c}\text { Numune } \\
\text { No }\end{array}$} & \multicolumn{2}{|c|}{ Relifex Film Tablet, 500mg. } \\
\hline & Bulunan $\mathrm{mg}$ & Bulunan \% \\
\hline 1 & 496,25 & 99,25 \\
\hline 2 & 505,50 & 101,10 \\
\hline 3 & 509,50 & 101,90 \\
\hline 4 & 504,00 & 100,80 \\
\hline 5 & 494,50 & 98,90 \\
\hline 6 & 500,50 & 100,10 \\
\hline 7 & 497,50 & 99,50 \\
\hline 8 & 496,00 & 99,20 \\
\hline 9 & 498,50 & 99,70 \\
\hline 10 & 501,50 & 100,30 \\
\hline & $\begin{array}{r}\text { Ortalama: } 500,37 \\
\text { SS: } 4,7889 \\
\%(B S S): 0,9570 \\
\end{array}$ & $\begin{array}{l}\text { Ortalama\%: } \\
100,08\end{array}$ \\
\hline
\end{tabular}

\subsection{Nabumeton İçeren Ticari Tabletlerde HPTLC İle Yapılan Miktar Tayini Yöntemi Sonuçları}

Yüksek performanslı ince tabaka kromatografisi ile uygulanan miktar tayini yönteminde Bölüm 2.6' da anlatılan yol izlenmiştir. Dalga boyu olarak $230 \mathrm{~nm}$ 'de daha iyi bir absorbans elde edildiği bilindiğinden bu dalga boyundaki alanlar alınmış, sonuçlar Tablo 6'da istatistiksel olarak değerlendirilmiştir.
Tablo-6. Nabumeton İçeren Ticari Tabletlerde HPTLC Yöntemi İle Miktar Tayini Sonuçları ve İstatistiksel Değerlendirmeleri

\begin{tabular}{|c|c|c|}
\hline \multirow{2}{*}{$\begin{array}{c}\text { Numune } \\
\text { No }\end{array}$} & \multicolumn{2}{|c|}{ Relifex Film Tablet, 500mg. } \\
\cline { 2 - 3 } & \multicolumn{2}{|c|}{ Dalga Boyu: 230 nm } \\
\cline { 2 - 3 } & Bulunan mg & Bulunan \% \\
\hline 1 & 519,00 & 103,80 \\
\hline 2 & 510,00 & 102,00 \\
\hline 3 & 522,50 & 104,50 \\
\hline 4 & 516,00 & 103,20 \\
\hline 5 & 518,50 & 103,70 \\
\hline 6 & 525,50 & 105,10 \\
\hline 7 & 521,50 & 104,30 \\
\hline 8 & 508,00 & 101,60 \\
\hline 9 & 511,00 & 102,20 \\
\hline 10 & 517,00 & 103,40 \\
\hline & Ortalama: & \\
& 516,90 & Ortalama\%: \\
& SS: 5,7339 & 103,38 \\
& $\%(B S S): 1,1092$ & \\
\hline
\end{tabular}

\section{Sonuç ve Tartışma}

$\mathrm{Bu}$ çalışmada, çeşitli aletsel analiz yöntemleri kullanılarak Türkiye'de Relifex adi altında piyasada bulunan nabumetonun tabletlerdeki miktarının tayini için yeni yöntemler geliştirilmiştir.

Nabumeton, non-steroidal antienflamatuar etkili romatoid artrit ve osteoartrit tedavisinde endike bir bileşiktir. Asidik olmayan, naftilbutanon türevi bir ilaç olan nabumeton analjezik ve antipiretik etkiye sahiptir. Vücutta karaciğerden geçerken hızlı bir şekilde, ana aktif metaboliti olan 6-metoksi-2- naftilasetik asite (6-MNA) dönüşür (Boyle E.A. ve ark.). 6-MNA prostaglandin sentezinin potent bir baskılayıcısıdır. Bu metabolitin asetik asit türevi olması nedeniyle nabumeton arilasetik asit prekürsörleri gubunda yer almaktadır. 
Nabumetonun monografi İngiliz ve Avrupa Farmakopesinde yer almaktadir. Avrupa Farmakopesinde etken maddeye yönelik spesifikasyonlar bildirilmiştir. Burada müstahzarlardaki miktarlarının tayini ile ilgili bir yöntem verilmemektedir. İngiliz Farmakopesinde yer alan HPLC yönteminde kullanılan kolonun zor bulunması nedeniyle, nabumeton içeren preparatların miktar tayin yönteminde firma tarafından bildirilen UV yöntemi uygulanmaktadır.

Türkiye'de Relifex film tablet adıyla üretilen nabumeton için firma tarafından bildirilen ve kontrollerde uygulanan UV Spektroskopisine dayanan bir miktar tayini yöntemi kullanılmaktadır. $\mathrm{Bu}$ yöntemde 332 nm'deki absorbans değerlerinden hareketle $100 \mu \mathrm{g} / \mathrm{mL}$ konsantrasyondaki çözeltilerden miktar tayini yapılmaktadır.

$\mathrm{Bu}$ çalışmada, nabumetonun tabletlerdeki miktarının tayin edilebilmesi için değişik yöntemler geliştirilmiş ve geliştirilen yöntemler ticari tabletlere uygulanmıştır. $\mathrm{Bu}$ amaçla yapılan çalışmalarda 4 ayrı yöntem ortaya konulmuştur. $\mathrm{Bu}$ yöntemler sirasiyla;

1) Yüksek Performanslı İnce Tabaka Kromatografisi (HPTLC)

Yöntemi

2) Yüksek Basınçlı Sıvı Kromatogafisi (HPLC) Yöntemi

\section{3) ${ }^{1} \mathrm{H}-\mathrm{NMR}$ Spektroskopisi Yöntemi}

4) LC/MS (Sıv1 Kromatografisi/ Kütle Spektroskopisi) Yöntemi

Rutin analizlerde kullanılan UV yöntemi ile, absorbansin daha iyi olduğu 260 nm'deki absorbans değerleri kullanılarak standart kalibrasyon eğrisi hazırlanmakta ve ticari tabletlere uygulanmaktadır. Böylece tarafimızdan ortaya konulan yöntemlerle rutin analizlerde halen uygulanan yöntemin karşılaştırmaları yapılmıştır.

Yüksek Performanslı İnce Tabaka Kromatografisi yöntemi, bilinen ince tabaka kramotogafisine göre daha hızlı, hassas ve uygulama kolaylığı olan bir tekniktir. Otomatik örnekleyici ile numuneler plaka üzerine spreyleme şeklinde tatbik edilebileceği gibi plakaya dokunarak da uygulanabilmektedir. Tarayıcı ile geliştirilen plaka üzerindeki pikler taranarak grafik olarak sonuçlar elde edilmektedir. Girilen datalar yönünde standart ve numunelere ait elde edilen pikler cihaz tarafindan otomatik olarak karşılaştırılarak sonuçlan doküman halinde verilmektedir. Numunede bulunan bileşenlerin miktarının kantitatif tayini, lekelerin alanının standarta ait lekenin alanının karşılaştırılması ile yapilabilmektedir.

Yüksek Performanslı İnce Tabaka Kromatografisi cihazı kullanılarak kantitatif analiz çalışmalarına literatürde sıklıkla rastlanmaktadır. $\mathrm{Bu}$ tekniği kullanarak ilaç etken maddelerine ait safsızlıkların kontrolü ve belirlenmesi yapılabilmekte, kalibrasyon eğrisi hazırlanarak miktar tayini yapilabilmektedir.

Bu araştırmada HPTLC cihazı kullanılarak şartlar modifiye edilmiş, müstahzarlara uygulanmış ve tablet içinde nabumetonun yüzde miktarının tayini yapılmıştır. Firma spesifikasyonu olarak bildirilen parçalanma ürünlerinin tayininde elüent olarak kloroform kullanıldığında düzgün 
bir sürüklenme olmamış, sürüklenmeyi düzeltmek için ortama metanol ilavesi yapılmıştır. Nabumeton'un, yüksek performanslı ince tabaka kromatografisi yöntemi ile yapılan miktar tayininde en uygun haraketli faz olarak kloroform: metanol (97: 3) bulunmuştur. Miktar tayininde, $50 \mu \mathrm{g} / \mathrm{mL}$ konsantrasyondaki standart nabumeton çözeltisinden otomatik ömekleyici ile standart ve numune tatbikleri yapılmış ve $230 \mathrm{~nm}$ 'deki standart ve numune lekeleri taranarak yüzde nabumeton miktarı tespit edilmiştir.

Yüksek basınçlı sıvı kromatografisi preparatların ilaç miktar tayininde en fazla kullanılan yöntemlerden birisidir. Özellikle Amerikan Farmakopesinde çeşitli ilaçların miktar tayinlerinin bu yöntemle yapıldığı görülmektedir. Yüksek basınçlı sıv1 kromatografisi daha çok ayırma tekniği olmasına rağmen ilaç etken maddelerin farmasötik preparatlardaki miktar tayininde başarı ile kullanılmaktadır.

Yöntemde belirli konsantrasyonlarda hazırlanmış nabumeton çözeltisinin $5 \mathrm{~cm}$ 1şık yoluna sahip diyot array detektörlü (DAD) HPLC cihazına enjeksiyonu sonucu pik alanları ile konsantrasyon arasındaki ilişki doğrusal bulunmuş, grafiksel olarak gösterilmiş ve daha sonra ticari tabletin çözeltisi enjekte edilerek 4,48 dakikada bulunan pik alanından hareketle miktar tayini gerçekleştirilmiştir.

Yöntemde 230, 260 ve 332 nm'deki pik cevaplarının $\mathrm{S} / \mathrm{N}$ değerleri tespit edilmiş ve inilebilecek alt limit bakımından uygun dalga boyu olarak $230 \mathrm{~nm}$ ' nin olduğu gözlenmiştir. Deneyde nabumeton için 230 nm'de 100 ng/ $2 \mu L$ 'de limitine kadar miktar tayininin gerçekleşebileceği bulunmuştur.
${ }^{1}$ H-NMR Spektroskopisi ile miktar tayini yöntemi hassas, hızlı ve kolay uygulanabilmektedir. NMR Spektroskopisi yaygin olarak yapi aydınlatması çalışmalarında kullanılmaktadır. Ancak etken madde uygun çözücüsünde yeteri kadar çözünüyorsa ve spektrumun boş bölgelerinde sinyal veren ve aynı çözücüde çözünen bir iç standart bulunabilirse kantitatif analizde de başarı ile kullanılmaktadır. En büyük avantajı insan hatasının en aza indirgenmesidir. Deney sırasında oluşabilecek tek hata numunenin ve iç standartın tam olarak tartılamamasından kaynaklanmaktadır. Miktar tayinin tümü spektrum üzerinde integral değerlerinden hareketle yapıldığından ve bu değerler spektrometre tarafından otomatik olarak verildiğinden hata en aza indirgenmektedir.

Nabumetonun ${ }^{1} \mathrm{H}-\mathrm{NMR} \quad$ Spektroskopisi Yöntemi ile yapılan miktar tayininde en uygun çözücü olarak dmso-d $\mathrm{d}_{6}$, iç standart olarak ise benzil benzoat bulunmuştur. Miktar tayininde nabumetonun 3,85'de altınc1 konumundaki protonlarına ait sinyalin integral değeri ve benzil benzoatın 5,35 ppm'deki metilen protonuna ait sinyalin integral değeri kullanılmıştır. İki sinyal birbirinden izole olduğundan ve her iki bileşiğin diğer sinyalleri ile karışmadığından miktar tayini kolayca yapılabilmektedir. Yöntemin 20-30 dakika gibi çok kısa bir sürede tamamlanması da büyük avantaj sağlamaktadır.

LC/MS yöntemi HPLC yöntemine benzer bir yöntemdir. En önemli özelliği kütle spektroskopisinin detektör olarak görev yapmasıdır. Böylece hassasiyet daha da artmakta ve çok daha düşük konsantrasyonlarda çalışılabilmektedir. 
Non-polar bir bileşik olan nabumetonun teorik olarak APCI iyonizasyon tekniği kullanılarak çalışılması uygun gibi görünse de, APCI tekniğinde m/z $229(\mathrm{M}+1)^{+}$ pikinin kararlı olmadığı tespit edilmiş ve elektrospray iyonizasyon tekniği (ESI) kullanılarak miktar tayini gerçekleştirilmiştir. ESI iyonizasyon tekniği kullanılarak yapılan yöntemle $\mathrm{m} / \mathrm{z}$ $229(\mathrm{M}+1)^{+}$pikinin toplam iyon kromatagamindan hareketle HPLC'ye benzer bir şekilde miktar tayini gerçekleştirilmiştir. Miktar tayini deneyinde $100 \mathrm{pg} / \mu \mathrm{L}$ konsantrasyonundan $3 \mu \mathrm{L}$ enjeksiyon yapılmış ve $0,3 \mathrm{ng}$ limitine kadar inilmiştir. LC/MS yöntemine ait sonuçlar Tablo 7 'de verilmiştir.

Tablo-7. Minimum Tespit Limiti (LOD) ve Kantitatif Alt Limit (LOQ) Sonuçları

\begin{tabular}{|c|c|c|}
\hline $\begin{array}{c}\text { Enjeksiyon } \\
(\boldsymbol{\mu L})\end{array}$ & $\begin{array}{c}\text { Madde Miktarı } \\
(\mathbf{n g})\end{array}$ & $\begin{array}{c}\text { S/N } \\
\text { Değeri }\end{array}$ \\
\hline 20 & 2 & 8 \\
\hline 5 & 0,5 & 5 \\
\hline 3 & 0,3 & 3 \\
\hline 2 & 0,2 & - \\
\hline
\end{tabular}

$\mathrm{Bu}$ yöntem farmasötik preparatların yanı sıra vücut sıvılarındaki miktar tayininde başarı ile kullanılabilmektedir. Vücut sıvısında bulunabilecek diğer bileşikler HPLC'de tam olarak ayrılmasa da molekül ağırlıkları farklı olan bileşiklerden sadece istenilen ağırlıktaki bileşiğin TIC'i alınabildiğinden HPLC yöntemindeki gibi tam bir ayırım yapılmasına gerek yoktur. $\mathrm{Bu}$ da özellikle karışım halinde bulunan bileşiklerin miktar tayinlerinin kolaylıkla yapılabilmesini sağlamaktadır.

Dört ayrı yöntemin $500 \mathrm{mg}$ nabumeton içeren ticari tabletlere (Relifex film tablet) uygulanması sonucu elde edilen istatistiksel değerler Tablo 8 'de verilmiştir.
Tablodan anlaşılacağı üzere istatistiksel olarak miktar tayininde kullanılacak yöntemlerin içinde en uygun olanları tarafımızdan ortaya konulan yöntemlerdir. İstatistiksel değerlendirmemizde, küçük standart sapma değeri bu yöntemlerin uygunluğu hakkında fikir vermektedir.

Kolaylık, çabukluk ve cihaz imkanları bakımindan ise ${ }^{1} \mathrm{H}-\mathrm{NMR}$ ve HPLC yöntemi en üstün yöntemlerdir. LC/MS yöntemi diğer yöntemlere göre daha alt limitlere inebilmemizi sağlayan bir yöntemdir. $\mathrm{Bu}$ nedenle, LC/MS yöntemi nabumeton için biyolojik sıvılardaki miktar tayinlerinde başarı ile kullanılabilir. Ayrıca, ekonomik yönden değerlendirmede ${ }^{1} \mathrm{H}-\mathrm{NMR}$ yönteminin cihazın laboratuvarda bulunması durumunda en ekonomik yöntem olduğu, HPLC yöntemi ise kullanılan çözücüler ve kolon sebebiyle ${ }^{1} \mathrm{H}-\mathrm{NMR}$ yönteminden daha az ekonomik olduğu görülmektedir. Ancak, sıv1 kromatografin günümüzde hemen hemen her laboratuvarda bulunduğu düşünülürse uygulama yönünden önerilebilir. HPTLC cihazı ile uygulanan yöntem ise alternatif bir yöntem olarak uygulanabilir. $\mathrm{Bu}$ yöntem, başka bir teknikle etken madde ve parçalanma ürünleri tayininin yapılamadığ 1 durumlarda gerçekleştirilir.

Tablo-8. Miktar Tayini Yöntemlerinin İstatiksel Karşılaştırmaları

\begin{tabular}{|l|l|l|l|l|}
\hline \multicolumn{5}{|c|}{ Nabumeton Film Tablet, 500 mg } \\
\hline & & & & \\
& & & 1 & \\
& HPTLC & HPLC & & LC/MS \\
\hline Ortalama & 516,9 & 505,35 & 501,65 & 500,37 \\
\hline Ort. \& & 103,38 & 101,07 & 100,33 & 100,08 \\
\hline SS & 5,7339 & 2,6462 & 3,8009 & 4,7889 \\
\hline \% BBS & 1,1092 & 0,5236 & 0,7576 & 0,957 \\
\hline
\end{tabular}


$\mathrm{Bu}$ çalışmada, tez konumu belirleyen, çalışmalarımı yöneten, çalışmalarımın her aşamasında değerli katkılarını gördüğüm rahmetli hocam Prof. Dr. Tuncel

\section{Kaynaklar}

Akgün, H. , Balkan, A., Bilgin, A.A., Çalış, Ü. , Dalkara, S., Erdoğan, H. , Erol, D.D., Ertan, M., Özkanlı, F., Palaska, E., saraç, S., Şafak,C.: Farmasötik Kimya, Cilt 1, Irmak Matbaas1, Ankara. (2000).

Al-Momani, F.: Determination of Nabumetone and its Major Metabolite in Plasma and Tablet Formulations by Reverse- Phase HPLC, Analytical Letters, 30(14), 2485-2492. (1997).

Bartsch, H., Eiper, A., Kopelent-Frank, H., Stability Indicating Assays fort he determination of Piroxicam-compartison of methods, J. Pharm. Biomed.Anal., 20(3), 531-541.(1999)

Bayliss, M.K., Little, D., Mallett, D.N., Plumb, R.S.: Parallel Ultra- High Flow Rate Liquid Chromotography With Mass Spectrometric Dedection Using A Multiplex Elecreosprey Source For Direct Sensitive Determmination Of Pharmaceutical İn Plazma At Exremly High Throughput, Rapid Commun. Mass Sprectrom., 14(21),2039-2045.(2000).

Boyle, E.A., Mangan, F.R.: The Effect of a Noval, Non-Steroidal Anti-Inflammatory Compound, Nabumetone (BRL 14777), on

Cellular Infiltration into 24-hour Polyvinyl Sponge Implayns in the Rat, Compared with some Steroidal and Non-Steroidal Anti-Inflammatory Drugs, J. Pharm. Pharmacol., 34. 570-575. (1982)
ÖZDEN'e teşekkür ve şükranlarını sunar, Cenabıhak'tan rahmet dilerim. Mekanın cennet olsun hocam...

British Phamacopoeia, 1-11, Crown Copyright, London, 912-913. (1998).

Brooks, P.: Use and Benefits of Nonsteroidal Anti-inflammatory Drugs, The American Journal of Medicine, 104 (3A), 9S-13S. (1988).

Duncan, M.W.: Bİomedical Mass Spectrometry Unit, Universty of New South Wales, Sydney, Australia, NATO ASI Ser.,

C504 (Selected Topics in Mass Spectrometry in Biomoleculer Sciences), 103-119, Kluwer Academic Publishers Review Sec.9. (1997).

European Pharmacopoeia- Supplement, Council of Europe, Strasbourg, 11571158. (2001).

Goudie, A.C., Gaster, L.M., Lake, A W-, Rose, C.J., Freeman, P.C., Hughes, B.O.: 4-(6-Methoxy-2 naphtyl)butan-2-one and Related Analogues, a Novel Structural Class of Anti-lnflammattory Compounds, Joumal of Medicinal Chemistry, 21 (12), 1260-1264. (1978).

Kayaalp, S.O.: Rasyonel Tedavi Yönünden T1bbi Farmakoloji, Sekizinci bask1, 2. Cilt, Hacettepe-Taş Kitapçılık Ltd. Şti., Ankara. (1998).

Makhija, S.N., Vavia, P.R.: Stability Indicating HPTLC Method for the Simultaneous Determination of Pseudoephedrine and Cetirizine in Pharmaceutical Formulations, J. Pharm. Biyomed. Anal., 25 (3-4), 663-667,(2001). 
Mandell, B.F.: General Tolerability and Use of Nonsteroidal Anti- Inflammattory Drugs, The American Joumal of Medicine, 107 (6A), 72S-76S. (1999).

Nimesulide from Pharmaceutical Dosage Forms, J.Pharm. Biomed.Anal., 25 (3-4), 685-688. (2001).

Novakovic, J., Nesmerak, K., Nova, H., Filka, K.: An Hptlc Method For The Determination and The Purity Control Of Ciprofiloxacin $\mathrm{HCl}$ in Coated Tablets, $\mathrm{j}$. Pharm. Biyomed. Anal., 25 (5-6),957964.(2001).

Novakovic, J.: Validation of a Highperformance Thin Layer Chromatographic Method for trace analysis for some generic drugs affercting gastrointestinal function, J.AOAC Int., 83(6), 1468-1473.(2000)

Noyanalpan, N., Özden, T.: Quantative Determination of Meprobamate by NMR in commercial Oreparations Marketed in Turkey, Ank. Ecz. Fak. Mec., 7(2), 189195. (1977).

Özden, S., Özden, T., Yalçın, İ., Noyanalpan, N.: İndometasin'in Nükleer Manyetik Rezonans Spektroskopisi ile Yeni Bir Miktar Tayini Yöntemi, FABAD J. Pharm. Sci., 8, 142-9. (1983)

Patravale, V.B., D'Souza S., Narkar, Y.: HPTLC Determination of Nimesulide from Pharmaceutical Dosage Forms, J.Pharm. Biomed.Anal., 25 (3-4), 685-688. (2001).

Pouchert, C.J., Campbell, J.R.: The Aldrich Library of NAR Spectra., Aldrich Chemical Company, USA. (1974).

Schiffman, S.S., Zervakis, J., Westall, H.L., Graham, B.G., Metz, A-, Bennett, J.L., Heald, A.E.: Effect of Antimicrobial and Anti-inflammatory Medications on the Sense of Taste, Physiology \& Behavior, 69, 413-424. (2000).
Simultaneous Determination of Pseudoephedrine and Cetirizine in Pharmaceutical Formulations, J. Pharm. Biyomed. Anal., 25 (3-4), 663-667,(2001).

Skoog, D.A., Holler, F.J., Niemann, T.A.: Princiles of İntrumental Analyses, Fifth Edition, Harcourt Brace \& Company, USA. (1998).

Turzcan, J.W., Kram, T.C.: Determination of Meprobamate in tablets by NMR J: Pharm.Sci. 56(12), 1643-6. (1967).

USP 23, The United states Pharmacopeia, Rand McNally (1995)

Wolff, J.C., Hawtİn, P.N., Monte, S., Balogh, M., Jones, T.: The use of Particle Beam Mass Spectrometry for the Measurement of Imputities in a Nabumetone Diug Substance, Not Easily Amenable to Atmospheric Pressure Ionisation Techniques, Rapid Communications in Mass Spectrometry, 15, 265- 272. (2001). 